
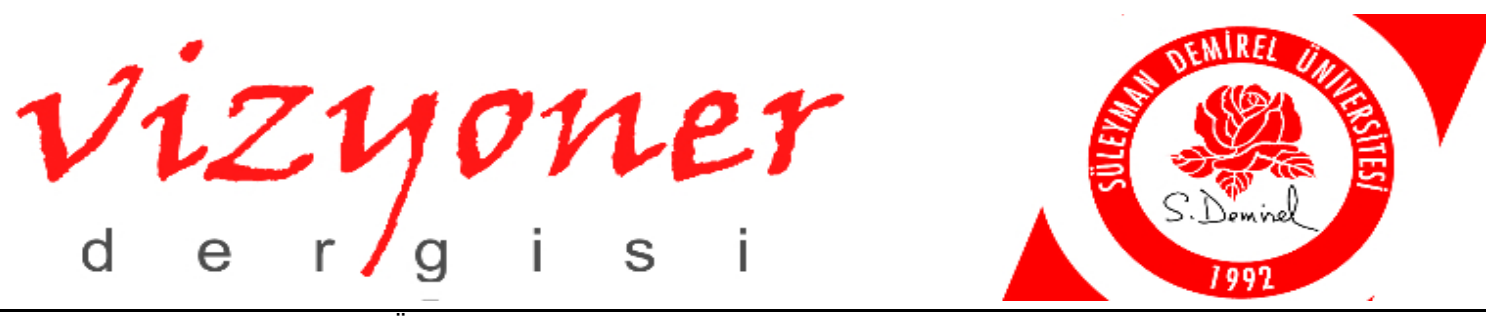

Süleyman Demirel Üniversitesi Vizyoner Dergisi, Yıl: 2019, Cilt: 10, Sayı: 24, ss.405-433. Suleyman Demirel University Visionary Journal, Year: 2019, Volume: 10, Number: 24, pp.405-433.

\title{
GÜÇ: FORMAL VE İNFORMAL YÖNDEN GÜCE KAVRAMSAL BİR BAKIȘ*
}

\section{POWER: A CONCEPTUAL OVERVIEW TO POWER IN TERMS OF FORMAL AND INFORMAL ASPECTS}

\author{
Dr. Öğr. Üyesi Ahmet ALKAN ${ }^{1}$ \\ Prof. Dr. Ramazan ERDEM ${ }^{2}$
}

\begin{abstract}
ÖZ
Genel anlamda güç; potansiyel etkidir. Yani başkalarını etkileyebilme potansiyelidir. Formal güç-informal güç ayrımına gidildiğinde ise: formal güç kişinin bulunduğu pozisyonundan dolayı başkalarını etkileyebilme potansiyeli; informal güç ise, kişinin bulunduğu pozisyondan bağımsız olarak diğerlerini etkileyebilme kapasitesidir. Literatür incelendiğinde güçle ilgili çok sayıda tanımlamanın ve güç kaynakları sınıflamasının yapıldığı görülmektedir. Yapılan güç kaynakları sınıflamasından en çok kullanılanı French ve Raven tarafindan yapılan beşli sınıflamadır. Bu taksonomiye göre güç kaynakları; ödül gücü, zorlayıcı güç, uzmanlık gücü, özdeşim gücü ve yasal güçtür. Fakat litaratürde güç kaynaklarının formal-informal ekseninde bir sınıflamasına rastlanamamıştır. Bu çalışmada formal ve informal yönleriyle güç olgusunun kavramsal çerçevesinin çizilebilmesi için bir derleme yapılması amaçlanmıştır. Yapılan çalışma sonucunda güç konusunun genel anlamda ele alındığı, formal güç informal güç bağlamında yapılan değerlendimelerin yetersiz olduğu görülmüştür. Ayrıca kurumların yönetilmesinde önemli bir araç olabilecek informal gücün yöneticiler tarafından göz ardı edilmemesi gerektiği sonucuna ulaşı1mıştır.
\end{abstract}

Anahtar Kelimeler: Güç, İnformal Güç, Güç Kaynakları.

JEL Sinıflandırma Kodları: M12, I1, M10.

\begin{abstract}
Generally, power is a potential effect. In other words, power is the potential to influence others. If a distinction between formal power and informal power is made, it can be claimed that formal power is the potential to influence others due to the position of the person while informal power is the capacity to influence others regardless of the position of the person. When the literature is examined, it is seen that there are many definitions about the power and the classification of power sources. The most used power classification is French and Raven's taxonomy which can be defined as quintet classification. According to this taxonomy, power sources are reward power, coercive power, expert power, referent power and legitimate power. However, the classification of power sources in terms of formal-informal has not been encountered in the literature. In thr study, it is aimed to make a compilation for the conceptual framework of power phenomenon with its formal and informal aspects. As a result of the study, it
\end{abstract}

\footnotetext{
Bu çalışma Ahmet ALKAN'ın “Örgütlerde İnformal Güç Olgusu: Hastane Çalışanları Üzerine Nitel Bir Araştırma” isimli doktora tezinden üretilmiştir.

1 Süleyman Demirel Üniversitesi, İktisadi ve İdari Bilimler Fakültesi, Sağlık Yönetimi Bölümü, ahmetalkan_88@hotmail.com, https://orcid.org/0000-0002-4964-8591

2 Süleyman Demirel Üniversitesi, İktisadi ve İdari Bilimler Fakültesi, Sağlık Yönetimi Bölümü, raerdem@yahoo.com, https://orcid.org/0000-0001-6951-3814
} 
is seen that the power issue is discussed in general and the evaluations made in the context of the formal power informal power are insufficient. In addition, it is concluded that the informal power, which may be an important tool in the management of institutions, should not be ignored by the managers.

Keywords: Power, Informal Power, Power Sources.

JEL Classification Codes: M12, I1, M10.

\section{GİRIŞ}

Gücün, ilişkisel bağlamda ele alındığında başlangıcı hakkında yorum yapabilmek oldukça zordur. Çünkü mitlerden dinlere, diğer canlı varlıklardan insanlara kadar her alanda güç ilişkisinden söz etmek mümkündür. Mitlerde tanrılar devamlı olarak güç savaşı içerisindedir. İslâm dini perspektifinden bakıldığında, ilk insan Hz. Âdem'in yaratılışı ile birlikte şeytan ile insan arasında bir güç mücadelesinin başladığı görülmektedir. Yine diğer canlılar arasındaki ilişkilere bakıldığında devamlı bir egemen olma gayreti görülecektir. Mitlerde, dinlerde ya da diğer canlılarda hâkim olan bu üstünlük kurma çabası insanlar arası ilişkilerde de yerini korumaktadır.

Güç bir olgu olarak ele alındığında ise örgütler ve yöneticiler açısından değerlendirilmelidir. Çünkü örgüt içerisindeki faaliyetlerin devamlılık arz ettirilebilmesi güç ilişkilerinin iyi yönetilmesine bağlıdır. Örgüt içerisinde bireyler birbirini etkileyebilmek, diğerleri üzerinde güç sahibi olabilmek için çeşitli kaynaklardan beslenmektedirler. Bu kaynaklar literatürde çeşitli şekillerde sınıflandırılsa da varlığı herkes tarafindan bilinen fakat bilimsel anlamda çok fazla dillendirilmeyen informal bakış açısıyla ele alınması ötelenmiştir.

Güce formal ve informal açıdan bakıldığında; genel anlamda güç potansiyel etkidir. Formal güç ise kişinin örgüt/organizasyon içerisindeki hiyerarşik pozisyonundan kaynaklanan yetkileri sayesinde diğer bireyleri etkileyebilme potansiyelidir. Buradan hareketle informal güç ise kişinin organizasyondaki pozisyonundan bağımsız olarak; kişisel özellikleri ve kişisel özelliklerine bağlı olarak sahip olduğu netvörk, maddi imkânlar, bilgi gibi kazanımlar sayesinde diğerlerinin davranışlarını etkileyebilme potansiyeli olarak tanımlanabilir.

Literatürde çok çeşitli güç kaynakları sınıflaması yapılsa da genellikle kabul gören French ve Raven tarafindan yapılan (ödül gücü, zorlayıcı güç, uzmanlık gücü, özdeşim gücü ve yasal güç) sınıflamadır. İnformal açıdan bakıldığında ise güç kaynakları güven, organizasyondaki pozisyon, yakın kişisel bağlar, itibar, sosyal sermaye, bilgi ve malumat şeklinde sayılmıştır. Yine French ve Raven'in sınıflaması da formal-informal açıdan ele alınarak özdeşim ve uzmanlık gücü informal güç kaynakları kapsamında değerlendirilmiştir.

Güç arayışı insanlık varolduğu sürece devam edecek bir durumdur. Çünkü insan yaşamında havanın önemi neyse insan ilişkilerinde ve örgütsel düzende güç olgusunun işlevi aynıdır. Gücü elinde bulunduranlar diğerlerine hükmeder ve onları istediği yönde sevk edebilme potansiyelini elinde bulundurur görüşünün gereği olarak güç elde etmeye çalışılır. Fakat insanların güç elde edebilmek ya da var olan güçlerini artırabilmek için geliştirdikleri taktiklerin neler olduğu, hangi güç kaynaklarından beslendiği tam olarak incelenmemiştir. Hâlbuki bilinmezlik belirsizlik demektir ki insanlar belirsizlikten kaçınma davranışı içerisindedir. Her ne kadar insanlar arasında varlığ hissedilse de örgütlerdeki informal güç ilişkileri, bilimsel anlamda, sitematik bir biçimde ve detaylı olarak ortaya konulamamıştır. Bu çalışma yukarıda bahsedilen literatürdeki boşluğu doldurmak ve örgütlerdeki formal-informal güç ilişkilerinin resmini çizmek amacıyla yapılmaktadır. Bu bağlamda çalışmada güç olgusu formal ve informal yönleriyle kavramsal açıdan ele alınmıştır.

\section{GÜÇ}

Güç; hayatın her alanında karşılaşılan bir durumdur. Fakat kendisi ile ilgili deyim ve atasözleri yediden yetmişe herkesin dilinde olmasına rağmen kavramsal olarak tanımlanması oldukça zordur. Çünkü iki canlı varlığın olduğu her durumda mutlaka güç ilişkilerinden söz edilecektir. Özdemir (2008: 117) bu ilişkilerin çokluğunun gücü geniş kapsamlı ve belirsiz bir hale getirdiğini vurgulamış, bu geniş kapsam ve belirsizliğin çok sayıda unsuru dikkate almayı gerektirmesinden dolayı gücün tanımlanmasını oldukça zorlaştırdığını dile getirmiştir.

Yine Bayraktaroğlu da gücün tanımlanması ve kavramsallaştırması zor, karışık bir kavram (Bayraktaroğlu, 2000: 118) olduğunu ifade etmektedir. Bu zorluğun nedeni belki de mutlak gücün yokluğu, onun yerine zaman ve duruma göre değişen güç ilişkilerinin varlığı olarak düşünülebilir. Her ne kadar tanımlanması zor olsa da tüm ilişkilerde kendisinden bahsedilen bir kavram olması hasebiyle güç; üzerinde araştırma ve ölçüm yapılmasını hak etmektedir. 
Çünkü insanlık tarihi kadar eski olduğu düşünülen güç ilişkilerinin ifade edilebilmesi için, güç kavramının tanımlanması da bir gereklilik arz etmektedir. Binaenaleyh; bilinmeyende, belirsizlik hâkim olan ortamlarda gizem vardır ve bu gizemin çözülmesi için o şeyin tanımlanması gerekir. Güç kavramı da bu belirsizliğin giderilmesi için farklı dönemlerde çeşitli yazarlar/düşünürler tarafından çeşitli şekillerde tanımlanmıştır.

Ünlü sosyolog Max Weber gücü (macht), sosyal ilişkide bulunan bir aktörün, sonuçları her ne olursa olsun, direnişe rağmen kendi isteklerini yerine getirebilme ihtimali (Weber, 1947: 152) olarak tanımlamıştır. Benzer şekilde "Essays in Sociology" adlı eserinde gücü bir ya da birden fazla kişinin toplumsal eylem içerisinde, bu eyleme katılan kişilerin direncine rağmen, kendi iradelerini gerçekleştirme şansı olarak ifade etmiştir (Weber, 1946: 180). Blau ise gücü geniş anlamda kullanarak Max Weber’i gücü dar anlamda kullanması noktasında eleştirmiştir.

Blau'ya göre geniş anlamda güç; diğerlerinin bir şeyler yapmaları için ödüllendirilerek kendi isteklerine razı olmaları amacıyla harekete geçirilmesi konusunda kişiler ya da gruplar arasındaki her türlü etkidir (Blau, 1986: 115). Fakat bakıldığında Blau'nun da gücü bir boyutuyla (ödül gücü) ifade ettiği görülmektedir. Gücün diğer boyutları (ceza gücü, uzmanlık gücü, yasal güç, karizmatik güç vb.) tanımda geçmemiş ya da onları çağrıştıracak ifadeler kullanılmamıştır.

Dahl ise gücü; B'nin A olmadan yapmayacağı bir şeyi, A sayesinde yapması durumunda ortaya çıkan durum, yani takipçilerin aksi takdirde yapmayacakları bir şeyi yaptırabilme yeteneği şeklinde tanımlayarak (Dahl, 1957: 203) gücün iki veya daha fazla kişi arasındaki ilişkileri içerdiğini vurgulamıştır. Gücü bağımlılık çerçevesinde ele alan Emerson (1962: 33) gücü A'nın B üzerindeki gücü, B'nin A'ya olan bağımlılığına eşittir (Pab=Dab) şeklinde formüle etmektedir.

Amaca dönük tanımlara bakıldığında Kanter gücü; bir kişinin ulaşmaya çalıştığ 1 hedefleri için ihtiyaç duyduğu şeyleri elde etme, kaynakları seferber etme ve bir şeyleri gerçekleştirebilme yeteneği (Kanter, 1993: 166) olarak tanımlarken Daft ve diğerleri, bir organizasyon içindeki bir kişinin veya birimin istenen sonuçlara ulaşmak için diğer kişileri etkileme yeteneği (Daft et al., 2010: 542) olarak tanımlamaktadırlar. Mintzberg (1983: 4) sonuçlara vurgu yaparak gücü en basit (sade) haliyle örgütsel sonuçlarl etkileme kapasitesidir şeklinde tanımlamıştır.

Organizasyondaki her yönetici dar anlamda bulunduğu birimi, geniş anlamda ise organizasyonu amaçlarına ulaştırmak için çabalar. Fakat yöneticilerin her işi kendisinin yapabilme imkânı yoktur. Yönetim faaliyetinin gereği olarak yöneticinin bazı işleri başkalarına yaptırabilmesi gerekmektedir. Başkalarına iş yaptırabilmek ise belirli bir güce sahip olabilmeyi gerektirir. Gibson ve diğerleri (1991: 330) gücü bu minvalde tanımlayarak; yapılması istenilen bir şeyin, başkaları vasıtasıyla, istenildiği şekilde yaptırılabilmesi yeteneği şeklinde ifade etmişlerdir. Yine Salancik ve Pfeffer'e (1977: 4) göre güç, kişinin yapmak istediği şeyi başkalarına yaptırabilme yeteneğidir.

Köken açısından bakıldığında ise güç (power) kelimesi eski Latince "potere” kelimesinden gelmektedir ve anlamı - ebilmek-abilmektir. Birini boyun eğmeye zorlama yeteneği, harekete geçme ya da etki üretebilme yeteneği olarak ifade edilir (Gove, 1981: 1778). Aynı zamanda güç potansiyel etkidir (Raven, 1993: 232; Gold, 1968: 252). Yani bir tarafın; diğerinin tutum ve/veya davranışını etkileme yeteneğidir (Rahim and Buntzman, 1989: 196). Diğer bir ifadeyle kişinin -ebilme seviyesine erişerek başkaları üzerinde bir etki oluşturabilmesidir.

"Eylem" ve güç kavramı arasında mantıksal bir bağ vardır. Yapabilmek, -ebilmek (can/ be able to) yardımcı filleri güçten bağımsız düşünülemez. Eylem ile güç arasındaki ilişki basitçe ifade edilmek istenirse: eylem sonuçlara ulaşılması için araçların kullanılmasını gerektirir. $\mathrm{Bu}$ sonuçlara aktörlerin (bireylerin) olaylara doğrudan müdahalesi yani "niyetli eylemleriyle" ulaşılır. Güç ise bu araçların oluşturulabilmesi için kaynakları harekete geçirebilme kapasitesini ifade eder. Yani en genel anlamıyla güç, insan eyleminin dönüştürücü kapasitesini ifade eder, dar anlamıyla ise istenilen sonuçlara ulaşabilme kapasitesi olarak tanımlanabilir. Güç kapasiteyi ifade ediyorsa o zaman uygulandığı anda ortaya çıkan bir durum değildir. Yani gelecekte kullanılmak üzere saklanan güçten söz edilebilir (Giddens, 1993: 116-118). Güç birey ya da grupların, başkalarının direnmesine rağmen, kendi çıkarlarının veya düşüncelerinin dikkate alınmasını sağlayabilme yeteneğidir. Zira güç, bütün toplumsal ve bireysel ilişkilerin temel öğesidir (Giddens, 2005: 418). Aslında güç ilişkilerinde bir paradoks hâkimdir. Yani ilişkiler gücü etkilerken (artırma ya da azaltma noktasında) aynı zamanda güçten de etkilenmektedir. Çünkü güçten bahsedebilmek için en az iki canlı varlığın arasında en az bir ilişkinin yaşanmış ya da yaşanıyor olması gerekir.

Yapılan güç tanımları incelendiğinde gücün ilişkisel olduğu görülecektir. Binaenaleyh bir kişinin gücü tek başına bir anlam ifade etmeyecek, ancak başkaları ile ilişskilendirildiğinde (A kişisi B kişisini etkilediği durumda) anlam ifade edecektir. Northcraft ve Neale (1990: 324) bu durumun bir zorunluluk olduğunu ifade ederek, güçten 
bahsedilebilmesi için en az iki kişiden ya da iki canlı varlıktan söz edilmesi gerektiğini, gücün bu iki şey arasındaki ilişkiden ortaya çıkacağını vurgulamaktadırlar.

Yine güç konusunda yapılan tanımlara bakıldığında algı, kapasite, etki, yetenek, ilişki, bağımlılık kavramlarının öne çıktığı görülmektedir. Yani bir kimsenin güç sahibi olup olamayacağının kararını veren karşı tarafın algısıdır. Cartwright ve Zander bu durumu; güç, karşı tarafın algısı ve ihtiyacı nispetinde anlam ifade eder şeklinde özetlemişlerdir (Cartwright and Zander, 1968: 217). Örneğin A kişisi çok iyi bir bilgisayar uzmanı olabilir. Eğer diğer insanlar bunu bilmiyorlarsa ya da buna ihtiyaçları yoksa A kişisi uzmanlık gücüne sahip değildir denilebilir (Bateman and Zeithaml, 1990: 484). Ya da A kişisi bilgisayar bilgisine sahip olduğu halde bu durum karşı taraftan böyle algılanmıyorsa yine A kişisinin uzmanlık gücüne sahip olmadığı söylenilebilir.

Güç bireyin sahip olduğu kapasiteyi bir ilişki içerisinde kullanmasını ve/veya kullanmak için çabalamasını esas alır. Herhangi bir sosyal ilişki içerisine girmeyen bireyin güç sahibi olup olmadığ bilinemez. Güçle ilgili önemli hususlardan bir tanesi; birine güç sahibi denilmesi için güç kaynaklarını fiilen kullanması zorunlu değildir. İlişkideki etkilenen durumunda olan tarafın etkileyende bu kaynakların olduğu algısı yeterlidir (Yıldırım, 1998: 52). Zira, Raven "güç potansiyel etkidir" tanımıyla tam da bunu ifade etmek istemektedir.

Parsons güç kavramının gerek sosyal bilimlerde gerekse siyaset bilimi ve sosyolojide tam olarak oturmuş bir kavram olmadığını ifade etmiştir (1957: 139). Güç literatürü incelendiğinde en önemli sorunlardan birinin terimlerin çoklu kullanılması olduğu görülecektir. Yazarlar güç hakkında kavramsal anlamda fikir birliğine varamadıkları gibi onu nasıl adlandıracakları konusunda da hemfikir olamamışlardır. Güç (power) üzerine çalışması bulunan düşünürler güç yerine kuvvet (force), etki (influence), otorite (authority), yaptırım (sanction), ceza (punishment), ikna (persuasion), kontrol (control), zorlama (coercion) ve daha birçok terim kullanmışlardır (Russell, 1998: 10). Aynı sorun günümüzde de devam etmektedir. Özellikle çeviri kitaplarda ve Türkçe yazılmış kaynaklarda bu durum mevcuttur. Güç yerine otorite, otorite yerine güç diyenler, güç ile iktidarı birbirinin yerine kullananlar oldukça fazladır.

Yukarıda görüldüğü gibi güç kavramı çeşitli disiplinlerde çok çeşitli şekillerde ifade edilmiştir. Hatta çeşitli kavramlar birbirlerinin yerine de kullanılmıştır. Fakat bu çalışmanın asıl amacı "disiplinlerde gücün algılanışı" ya da gücü yeniden tanımlamak olmadı̆̆ından çeşitli güç tanımları verilmiş, yeni bir güç tanımlamasına gidilmeden, muhakeme okuyucuya bırakılmıştır. Ancak her ne kadar bir tanımlama verilmese de araştırmacının kendisine yakın hissedip çalışmada benimsediği tanım "güç potansiyel etkidir" olacaktır.

Öncesinde Weber, Pareto ve Mosca sonrasında Russell ve Lasswell gibi düşünürler her ne kadar gücün bazı boyutlarını keşfetseler de güç konusunda bir fikir birliğine varamamışlardır (Dahrendorf, 1959: 166). Emerson ilerleyen yıllarda bu durumu 'güçle ilgili ampirik ve teorik olmak üzere hem küçük gruplarla hem de büyük gruplarla yapılmış geniş çaplı araştırmalar olmasına rağmen istenilen düzeyde sonuçlara ulaşılamamış ve güçle ilgili bilgilerimiz Weber'in bıraktığının çok ötesine geçememiştir' (Emerson, 1962: 31) şeklinde dile getirmiştir. Günümüz açısından değerlendirildiğinde güçle ilgili çok fazla çalışma yapılmış olsa da tanımlar noktasındaki bulanıklıklar hâlâ devam etmektedir. Fakat güç konusunda artık mesafe kat edememiş durumda değiliz. Emerson'un söylediğinin aksine, uzunca bir mesafe kat edilmiş durumda.

Bayraktaroğlu gücün kavramsallaştırılması ile ilgili çalışmaların Laswell ve Kaplan'ın 1950 yılında yayınladıkları Güç ve Toplum (Power and Society) adlı eserine dayandığını ifade etmektedir (2000: 110). Fakat literatür detaylı araştırıldığında sosyal psikoloji alanında güçle ilgili yapılan çalışmalarda genel olarak Thomas Hobbes'un 1651 yılında yayınladığı Leviathan adlı eserine atıf yapıldığı görülmektedir. Bu çalışmada güç motivasyonu ve gücün sosyal sonuçları ele alınmıştır. Sonrasında Nietzsche'nin 1912 yılında yayınladığı Der Wille zur Macht adlı eserinde ve sosyal psikoloji alanındaki daha bir çok düşünürün çalışmalarında güç konusuna değinildiği görülmektedir (Cartwright, 1959: 1).

Gücün kavramsallaştırılmasına yönelik çalışmaların başlangıcı noktasındaki muallak durum güçle ilgili yapılan çalışmalar ve gelinen nihai nokta konusunda da hâkimdir. Luthans stres yönetimi, grup, örgüt gibi konuların; uzun yıllardır örgütsel davranışın konuları haline gelse de aynı dinamiği güç ve politikanın henüz tam anlamıyla yakalayamadığını ifade ederek 'güç ve politika konusu kapalı kapılar arkasından çıkartılarak örgütsel davranışın dinamikleri haline getirilmelidir' demektedir (Luthans, 2011: 312). Fakat Luthans bu şekilde söylerken Fabianke ve Isaac, Luthans'ın söylediğinin tam zıddını ifade etmektedir. Onlara göre güç yıllardır hem bilimsel hem de sosyal bağlamda incelenen bir kavramdır. Birçok açıdan tanımlanmaya çalışılmış ve nasıl elde edileceği, nasıl kullanılacağı ve nasıl korunacağı (Fabianke, 1999: 13), iki unsurun (kişi, grup vb.) davranışları arasındaki illiyet bağı anlamına gelen gücün çeşitli varyasyonları çok sayıda çalışmaya konu olmuştur (Isaac, 1987: 7). Netice olarak 
günümüzde gücün çok sayıda çalışmanın konusu haline geldiği söylenebilir. Bu meyanda Luthans'ın ifadelerinin, güç çok sayıda çalışmanın konusu olsa da daha aydınlatılamamış birçok yönü bulunmaktadır şeklinde yorumlandığında daha doğru olacaktır. Çünkü İngilizce literatürde gücün kaynakları arasındaki ilişkiyi (Rahim et al., 2001; Rahim, 2004;) güç kaynaklarının doğruluğunu (Rahim and Magner, 1996) test etmeye, "güç nedir?" sorusunun cevabını bulmaya, gücün doğasını, kaynaklarını araştırmaya yönelik çok sayıda çalışma (French and Raven, 1959; Lusch, 1976; Kanter, 1981; Cobb, 1984; Isaac, 1987; Rahim 1988; Munduate and Dorado, 1998) yapılmıştır. Yine Türkçe literatür incelendiğinde, özellikle son 25-30 yıldır güç konusunda sosyolojiden yönetim bilimlerine, sağlık kurumlarından üniversitelere, işletmelerden fabrikalara, tekstil sektöründen inşaat sektörüne çok çeşitli alanlarda kavramsal (Bayrak, 2000; Çörekçioğlu, 2014; Başaran ve Duygulu, 2014; Kemikkıran, 2015; Kızanlıklı, vd., 2016; Çalışkur, 2016) ve uygulamalı (Altay, 2004; Yaman ve Irmak, 2010; Polat ve Meydan, 2011; Çavuş ve Harbalıoğlu, 2016) olmak üzere çok sayıda makale ve tez yazıldığı görülmektedir.

Güç kavramı hem İngilizce hem de Türkçe literatürde çeşitli kavramlarla aynı anlamda ya da iç içe kullanılabilmektedir. Özellikle çevirilerden ya da kullanıldığ 1 disiplinlerden kaynaklı olarak çeşitli kavramların yerine kullanılabilmekte ya da bu kavramlar güç kavramının yerini alabilmektedir. Bu sebepten güç kavramının benzer kavramlarla olan ilişkisinden bahsedilerek benzer kavramların açıklanması gücün farkını ortaya koyacaktır.

\subsection{Gücün Benzer Kavramlarla İlişkisi}

Tüm kavramlarda olduğu gibi güç kavramı da çeşitli kavramlarla ilişki içerisinde kendisine anlam kazandırmaktadır. Bu ilişki bazı kavramların birbirinin yerlerine kullanılması şeklinde olabildiği gibi bazılarının sonucu, bazılarının sebebi olabilmektedir. Hatta bazen birbiri ile ilişkisi sürekli bir döngü içerisinde olabilmektedir. Bu kavramlara netlik kazandırılarak güç ile ilişkilerinin ortaya konulması literatürdeki muğlaklığı biraz olsun netleştirme açısından faydalı olacaktır.

\subsubsection{Güç-Otorite İlişkisi}

Weber gücü (macht), sosyal ilişkide bulunan bir aktörün, sonuçları her ne olursa olsun, direnişe rağmen kendi isteklerini yerine getirebilme ihtimali (1947: 152) olarak tanımlarken otoriteyi ise; bir kaynaktan gelen belirli (ya da tüm) emirlere emrin verildiği grup ya da kişiler tarafından uyulması ihtimali olarak tanımlamıştır (1947: 324). Yani bir kişi ya da grubu diğerinden üstün kılan meşru güçtür (Giddens ve Sutton, 2014: 361). Fayol'un penceresinden bakıldığında otorite; kumanda etme hakk1, kendine itaat ettirme gücü (Fayol, 2008: 25) iken Sennet'te (2011: 29) en genel anlamıyla otorite; iktidar koşullarını yorumlama, bir güç imgesi tanımlamak suretiyle denetim ve nüfuz koşullarına bir anlam verme çabası olarak ifade bulmuştur.

Yasal güç ile eş anlamlı olarak kullanılan otorite (Şimşek ve Çelik, 2011: 74) gücü meşrulaştırır ve bir güç kaynağıdır. Otorite diğer insanları kullanma (iş yaptırma) hakkıdır. Otorite güç kullanım şekli olduğundan dolayı güç otoriteyi de içeren daha geniş bir kavramdır (Kırel, 1998: 10). Yasaldır ve gücün kaynağıdır. Otorite başkalarını değiştirme ya da manipüle etme hakkıdır (Luthans, 2011: 313). Eşit olmayan insanlar arasında bir bağ (Sennett: 2011: 20) olarak ifade edilen otoritenin temel işlevi güç sahibi olmak ve bu güç sayesinde insanları disipline sokarak davranışlarını yönlendirmek ve daha yüksek bir standarda göre hareket etmelerini sağlamaktır (Sennett: 2011:27).

Weber otoriteyi 3 zeminde inceleyerek bunları; yasal otorite, geleneksel otorite ve karizmatik otorite şeklinde izah etmiştir (Weber, 1947: 328). Bu açıdan güce bakıldığında ekonomik güç, askeri güç, siyasi güç, bireysel güç vb. şeklinde gücün çeşitli zeminlere oturtulabildiği görülecektir. Yani gücün otorite ile benzer yönleri olduğu düşünülse de esasında otoriteden farklıdır.

Güç ile otorite arasındaki önemli fark; güç daha çok bireylerin kişilikleri ile ilgili olduğu halde otorite kişinin sosyal konumu (pozisyonu) ve rolleri ile ilgilidir. Örneğin bir demagog halka konuşma yaparken kişisel özelliklerinden dolayı onlar üzerinde güce sahipken; bir amir memurlar üzerinde, yönetici çalışanları üzerinde otoriteye sahiptir. Çünkü demagogun diğer insanları etkilemesi amir ve yöneticilerde olduğu gibi bulunduğu pozisyondan gelmemektedir. Diğer taraftan Weber'in de dediği gibi güç sadece gerçek bir ilişki iken, otorite hâkimiyet ve boyun eğmenin yasal bir ilişkisidir. Bu anlamda otorite yasal güç olarak tanımlanabilir (Dahrendorf, 1959: 166).

Güç ile otorite arasındaki ilişki "yetenek (ability)" kelimesine yapılan vurgu ile daha iyi anlaşılabilecektir. Otorite başkalarının faaliyetlerini yönlendirme hakkıdır. Otorite, ister sonuç alınsın ister alınmasın resmi olarak onaylanmış ayrıcalıktır. Buna karşın güç ise sonuç alabilme yeteneğidir (Kreitner, 2009: 399). Bazı durumlarda kişinin otoritesi olduğu halde gücü, gücü olduğu halde otoritesi olmayabilir. Örneğin uzmanlık gerektiren işlerde 
ya da teknik beceri gerektiren işlerde alt birimlerde çalışan birisi üst pozisyonda olan (otoritesi olan) birisine göre daha fazla güce sahip olabilir (Tutar, 2014: 211). Yani uzmanlık bilgisi sayesinde gücü vardır fakat daha alt birimde olduğundan dolayı otoritesi ya yoktur ya da üstlerine nazaran çok daha azdır.

Otorite-güç ilişkisini şekil 1.'deki gibi göstermek mümkündür.

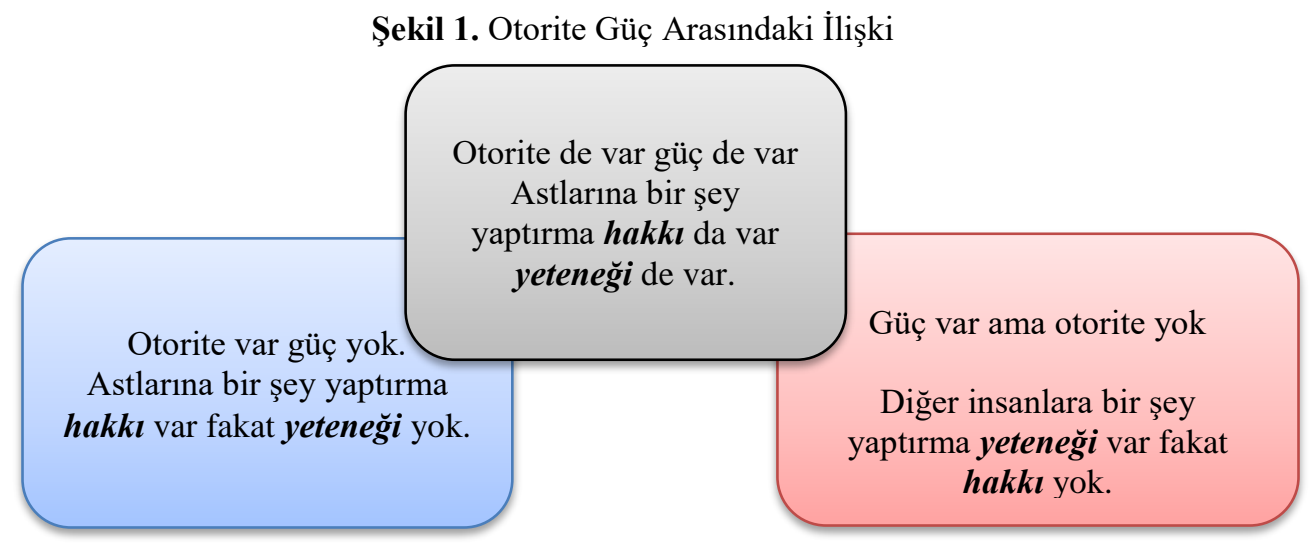

Kaynak: (Kreitner, 2009: 400).

Şekil 1.'de de ifade edildiği gibi, kişinin otoritesi olabilir ama gücü olmayabilir ki bu durumda yeteneği olmadığ için astlarına ya bir şey yaptıramayacak ya da bir şeyler yaptırmakta zorlanacaktır. Bir başhekimin diğer hekimlere yaptırım hakkı olmasına rağmen onları kendi isteği doğrultusunda yönlendirme yeteneğinin olmaması bu duruma örnek verilebilir. Bazen de gücü olabilir fakat otoritesi olmayabilir ki; yine bu durumda kişi astlarına bir şeyi resmi olarak ya yaptıramayacaktır ya da informal olarak yaptıracaktır. Hastanedeki bir asistan hekimin tek başına ameliyata girememesi (çünkü ekip lideri olma yeteneği var fakat yetkisi yok) ya da unvan olarak daha üst ya da aynı olan bir hekime bir şeyler yaptıramaması bu durumun pratikte yansımalarından biri olabilir. Her iki durumun da birlikte varlığı (otorite-güç) tüm kurumlar için istenen bir durumdur. Çünkü kişinin hem bir şeyi yapabilme kabiliyeti (güç) vardır hem de bunu yapma hakkı (otorite) vardır. Bu duruma güç kaynaklarına sahip bir tıp fakültesi dekanının hekimleri toplantıya çağırması örnek gösterilebilir.

Otoriteyi bir grubun ya da organizasyonun yöneticiye verdiği hak olarak gören Güney (2008: 20) güç-otorite ilişkisini şu şekilde ifade etmektedir:

- Güç otoriteyi de kapsayan bir kavramdır, yasal otoritesi olmadığı halde yöneticinin astlarını etkilemesi bunun örneğidir.

- Güç bir şeyi yapabilme yeteneği olmasına rağmen, otorite bir şeyi yapabilme hakkıdır.

- Bir yöneticinin otorite sahibi olması güç sahibi de olacağı anlamını taşımaz. Çünkü her otorite sahibi olan yönetici astlarını etkileyemeyebilir.

Özetle; otorite ile güç farklı kavramlardır. Kişi güç sahibi olup otoriteye sahip olmayabileceği gibi otorite sahibi olup güç sahibi olmayabilir. Fakat ikisinin aynı kişide aynı anda olması örgütler için en ideal durumdur. Gücün otoritenin kaplamında yer almasının yanında otorite hak kavramıyla, güç ise yetenek kavramıyla ifade bulmaktadır.

\subsubsection{Güç-Etki İlişkisi}

İnsan ilişkilerinde önemli bir yer tutan güç faktörü etkiden (etkileme) bağımsız düşünülemez. Bir yerde etki varsa güç de vardır. Çünkü “kim kimi etkiler?” sorusunun cevabı güçte gizlidir. Etkileyen taraf gücü elinde bulunduran taraf olacaktır (Sakallı, 2010: 86). Kökeninde güç; etki oluşturma kapasitesi ya da yetisi olarak görülürken etki, eyleme geçmiş güç demektir (Hogg and Vaughan, 2011: 271). Yani bir durumun kaynaktaki (güç sahibi) hali güç olarak ifade edilebilirken hedefin üzerindeki (uygulamadaki) görünümü etki olarak ifade edilebilir. Raven'in etki tanımıyla Rahim'in güç tanımları incelendiğinde bu durum daha da netleşecektir. Raven (1965: 371) etkiyi; bir kişi veya grubun -başka bir grubun tutum veya davranışlarına bağlı olarak- biliş, tutum veya davranışlarında meydana gelen değişim olarak tanımlarken, Rahim (1989: 545; 2004: 4) gücü; bir tarafın diğer bir tarafın tutumlarını, davranışlarını, fikirlerini, amaçlarını, ihtiyaçlarını ya da sahip olduğu değerlerini değiştirebilme ya da 
kontrol altına alabilme yeteneği olarak tanımlamıştır. Dikkat edildiğinde gücün bir kapasite ya da potansiyel olduğu, etkinin ise eylem olduğu görülecektir. Zaten Raven (1993: 232) gücü "potansiyel etki" (potential influence), etkiyi ise (1965: 371) "kinetik güç" (kinetic power) şeklinde ifade etmektedir.

Güç-etki ilişkisi farklı bir disiplinden verilecek örnekle daha iyi anlaşılabilecektir. Kinetik enerji ve potansiyel enerji düşünüldüğünde güç-etkileme ilişkisini anlamak daha da kolaylaşacaktır. Kinetik enerji etkiyi ifade ederken, potansiyel enerji gücü ifade eder. Örneğin yer çekimi (kütle çekim kuvveti) kanunu herkes tarafından bilinir. Dünya yüzeyinde yukarıdan bırakılan bir cisim yeryüzüne doğru düşer. Yani yeryüzünde bir çekim potansiyeli vardır (tıpkı güçte etkileme potansiyeli olduğu gibi), bir nesneyi çekmese de bu vardır, tıpkı güçte olduğu gibi. Boşluğa düşen bir nesnenin yeryüzüne doğru gidişini izlerken ise etkiyi görürüz. Yani elma ağacın dalındayken yer çekimi potansiyel (güç) durumda, rüzgâr vb. bir şeyin sarsmasıyla dalından kopan elma yere doğru düşerken kinetik (etki) durumdadır.

İnsanlar çocukluktan gelen çaresizliği ile baş edebilmek için güç arayışına girmektedir. Düz mantıkla düşünüldüğünde güçsüz bireylerin kendini koruyabilmek için ellerinde mutlaka bir silahı vardır. İşte güç arayışında olan kişilerin de ellerindeki silahı etkilemedir. Kipnis ve diğerlerinin (1980) yapmış oldukları çalışmada 8 etkileme boyutuna ulaşılmıştır. Bunlar; kendine güven (assertiveness), göze girme (yağcılık yaparak, yalandan sevgi gösterisiyle kendini sevdirmek, ingratiation), rasyonellik (rationality), yaptırım uygulama (sanction), karşılık sunma (mihnet altında bırakma, exchange), üste başvurma (olayı üste gönderme, upward appeal), engelleme (blocking), birlik oluşturma (coalition) boyutlarıdır. İlk dört etkileme boyutu tüm seviyelerde (ast, üst ve iş arkadaşları) görülürken; karşılık sunma, üste başvurma ve engelleme taktikleri üstü etkilemede kullanılmaktadır. Birlik olma boyutu ise astları etkilemede kullanılmıştır

Kelman (1958: 53) Jahoda'nın (1956) yapmış olduğu uyma sınıflamasından uyarlama yaparak üç farklı etki süreci olduğunu ve bunların itaat etme, özdeşleşme, içselleştirme olarak birbirinden ayrılabileceğini söylemiştir. Kişinin başka kişi ya da gruplardan olumlu tepkiler almayı umduğu, ödüllendirilmeyi beklediği ya da cezalardan kaçınmak için gösterdiği uyma davranışı itaat etme olarak ifade edilmiştir. Özdeşleşme ise diğer kişi ya da gruplarla ilişki kurmak ya da var olan ilişkinin sürdürülmek istendiği durumlarda ortaya çıkar. Çünkü bu kişi ya da gruplarla ilişki kurmak arzulanan bir durumdur. O yüzden konunun içeriği az ya da çok önemli değildir. Önemli olan arzulanan kişi ya da gruplar tarafından ifade edilmiş olmasıdır. Eğer kişi söylenen talimatın mevcut değerleriyle uyumlu olduğu için harekete geçerse içselleştirmeden söz edilir. Burada konunun içeriği önemlidir.

İnsanlar güç elde edebilmek ya da güçlerinin varlığını hissettirebilmek için etki/etkilemeden faydalanırlar. Çünkü etkileme eldeki en önemli silahtır. Etki etkilenen tarafta itaat etme, içselleştirme ya da özdeşleşme şeklinde tezahür edebilecektir. Eğer etkileme bu üç durumdan biri ile sonuçlanmışsa etkileyen taraf etkilenen taraf üzerinde güç elde etmiş olacaktır.

\subsubsection{Güç-Uyma İlişkisi}

Uyma bireyin kendi düşünce ve davranışını çeşitli sebeplere bağlı olarak değiştirmesi ve kendinden farklı gördüğü grup normu doğrultusunda görüş bildirmesi veya davranış sergilemesi şeklinde tanımlanabilir (Hortaçsu, 2012: 477). Jahoda uyma (conformism) davranışının itaat etme (compliance), ikna olma (consentience), uyumlu olma (conformance), yakınsama (convergence) olmak üzere dört şekilde gerçekleştiğini ifade etmiştir. İtaat etme kişinin önerilen duruma karşı çıktığında gelecekle ilgili beklentilerinin olumsuz yönde etkileneceğine inanmasından dolayı talimatları yerine getirme durumudur. İkna olma, çeşitli argümanlar sonucunda kişinin var olan direnç eğilimini değiştirerek talimatlara uymasıdır. Uyumlu olma ise gruptaki diğer kişilerin davranışlarına bakarak onlar gibi davranma yani onlara uyma durumudur. Yakınsama kendi fikrimize inandığımız halde sonucu bizi etkilemeyecek bir diş faktörün etkisinde kalınarak karar verme durumudur (Jahoda, 1956: 237).

Jahoda'nın yaptığı sınıflamadan uyumlu olma Asch'ın (1961) yaptığı deneyle ampirik olarak kendini göstermektedir. Deneyde Asch, katılımcılara üzerinde farklı uzunluklarda üç çizgi olan bir kart ve üzerinde birinci karttaki çizgilerden biriyle aynı uzunluğa sahip bir çizgi olan ikinci bir kart göstermiştir. Sonrasında katılımcılardan sırayla birinci karttaki hangi çizginin ikinci karttaki ile aynı uzunlukta olduğunu yüksek sesle söylemeleri istenmiştir. Sekiz erkekten oluşan grupta sadece bir kişi denek, diğerleriyse önceden bilgilendirilmiş ve belirli yerlerde denekten farklı cevap vermeleri istenmiş ücretli çalışanlardır. Deney çok çeşitli büyüklükte kişi sayısıyla tekrar tekrar denenmiştir. Deney sonucunda katılımcı deneklerin en az üçte biri yanlış cevabı onaylamıştır. Bazı katılımcılar hep çoğunluğun kararına uymuş bazıları ara sıra uymuş bazılarıysa hiç uymamıştır. Katılımcıların yarıdan fazlası en az bir kere çoğunluğa uymuştur. Asch'in çoğunluk etkisi dediği bu olayda çoğunluğun gücünün azınlığı nasıl etkilediği ve uyumu sağladığı ortaya çıkmıştır. 
Süleyman Demirel Üniversitesi Vizyoner Dergisi, Yıl: 2019, Cilt: 10, Sayı: 24, ss.405-433.

Suleyman Demirel University Visionary Journal, Year: 2019, Volume: 10, Number: 24, pp.405-433.

\subsubsection{Güç-Bağımlılık İlişkisi}

Gücün en önemli özelliği bă̆ımlılı̆̆ın bir fonksiyonu olmasıdır (Robbins and Judge, 2011: 416). B'nin A'ya olan bağımlılığı arttıkça A'nın daha fazla gücü olduğu ortaya çıkmaktadır. A'nın gücü B'nin algısına ve A'nın güç alanında bulunanların B için ne derece önemli olduğuna bağlıdır. Bağımlılıkta etkili olan iki önemli faktör vardır. Birincisi tarafların bağımlılıktan elde edecekleri şeye atfettikleri değerdir (motivational investment). İkincisi ise, bu ilişkiden elde edilecek sonucun diğer bireylerden (kaynaklardan) elde edilebilme ihtimalidir (Emerson, 1962: 32). Atfetme değeri ve alternatifler sırasıyla örneklendirilirse; B kişisinin A kişisi ile olan ilişkisinden doğacak çıktıya B kişisinin atfettiği değer arttıkça A kişisine olan bağımlılığı artacak, dolayısıyla A'nın B üzerindeki gücü artacaktır. B'nin A ile olan ilişkisinden elde edeceği değeri diğer kaynaklardan elde edebilme ihtimali düştükçe B'nin A'ya olan bağımlılığg artacak, dolayısıyla A'nın B üzerindeki gücü artacaktır (Doğan, 2012: 3).

Emerson'ın ifade ettiği bağımlılığı alt birimler açısından literatürde ilk defa ele alan Hickson ve diğerleri (1971) stratejik olumsallık teorisi (strategic contingencies theory) adını verdikleri teorilerinde gücü bağımlı değişken olarak ele almışlardır. Teoriye göre alt birimlerin gücü belirsizliklerle başa çıkabilmelerine, merkeziliklerine ve ikame edilemezlik durumlarına bağlıdır (Hickson et al., 1971: 216). Kaynakların kıt, önemli ve ikame edilemez oluşu ise bağımlığı artıracak diğer değişkenlerdir (Mintzberg, 1983: 24).

Güç doğası gereği asimetrik bir kavram olup bireyin bir ödülü birisinden geri almasına ve başkalarına cezai yaptırımlar uygulamasına dayanmaktadır. Gücün kaynağı ise tek taraflı bağımlılıktır. Çünkü karşılıklı dayanışma (çift taraflı bağımlılık) ve eşit kuvvetlerin karşılıklı etkileşimi güçsüzlüğe işaret eder (Blau, 1986:117-118). Tek taraflı bağımlılıkta sınırlı kaynağı elinde bulunduran kişi (bağımlı olunan) diğer taraf üzerinde önemli bir güce sahip olacaktır. Riggio (2016: 384) önemli denebilecek derecede bir tecrübeye sahip olan kişinin tek taraflı bir güç kaynağına sahip olduğunu ifade etmektedir. Çünkü o tecrübeye sahip olmayanlar işlerini yaptırabilmek için tecrübeli kişiden yardım alacaklardır. Örneğin bir subay düşünüldüğünde her ne kadar uzmanlık bilgisi bir çavuştan daha fazla olsa da tecrübesi olmadığından dolayı ilk atandığında bir çavuşla iyi geçinmelidir.

Açık sistem içerisinde bulunan tüm canlı varlıklar (organizmalar) ya da kurumlar yaşamlarını sürdürebilmek için çevreleriyle sürekli alışveriş içerisinde bulunurlar. Çevrelerinden kaynak temin ederek çevrelerine çıktı dağıtırlar. İhtiyaç duyulan kaynakların önemi çevreye olan bağımlılı̆̆ın çerçevesini belirler (Koçel, 2011: 352). Kurumlardaki alt birimlerin (alt pozisyondaki çalışanların) gücü incelendiğinde bağımlılığın bileşenlerinden olan kaynak bağımlılığının önemi görülecektir. Çünkü organizasyonel yapıdaki birimler kendi aralarında para, personel, bilgi gibi değerli emtiaların alışverişini yapmak durumundadır. Diğer birimin ihtiyaç duyduğu kaynağı elinde bulunduran birim, diğer birimin faaliyetlerini sürdürebilmesi için bu kaynaklara ihtiyaç duyacağından dolayı, diğer birim üzerinde bir güce sahip olacaktır (Greenberg vd., 2000: 378).

Esasında kaynak bağımlılığı teorisi örgütsel dünyayı açıklamada güç bakış açısını kullanır. Kritik kaynaklar kimin elindeyse güç ondadır (Üsdiken, 2005: 277). Çünkü diğer sosyal sitemlerde olduğu gibi organizasyonlarda da güç kritik ve kıt kaynakların etrafında toplanmıştır. Bunun yanında organizasyonlar en önemli amacı olan varlığını sürdürebilmeyi ancak ihtiyaç duyduğu kaynakların teminini garantileme ile gerçekleştirebilecektir. İhtiyaç duyulan kaynakların temin edebilmesi için çevreye duyulan ihtiyaç da kaynak bağımlılı̆̆ı olarak kendini gösterecektir (Pfeffer and Salancik, 2003: 258). Alternatif kaynaklar azaldıkça kişinin gücü artar. Yeri doldurulamayacak kaynağı kendisinde bulunduran kişiler güç kazanırlar. Böylece kritik kaynakları elinde bulunduran kişiler diğerlerinin kendilerine olan bağımlılı̆̆ını artırarak istedikleri sonuçları elde ederler. O yüzden güç elde etmenin basit iki yolu; dışarıya olan bağımlılı̆̆ı azaltıp dışarının bize olan bağımlılığını artırmaktır (Brass, 1984: 520; Brass, 2002: 139; Morgan, 2006: 170). Kaynak bağımlılığı teorisinin her ne kadar Pfeffer'in daha önce yapmış olduğu çalışmalarda adı geçse de bir yaklaşım olarak ortaya koyulmak üzere kullanımı Aldrich ve Pfeffer'in (1976) "Environment of Organization" adlı eseri ile olmuştur. Fakat ifade ettiği bakıș açısının etkisinin artması Pfeffer ve Salancik'in Örgütlerin Dışarıdan Denetimi: Kaynak Bağımlılığı Bakış Açısı (The External Control of Organisations: A Resource Dependence Perspective) adlı çalışmasıyla olmuştur (Üsdiken, 2007: 77).

Emerson'un (1962) bağımlılık teorisi, Hickson ve diğerlerinin (1971) stratejik olumsallık teorisi ve Pfeffer ve Salancik'in (2003) kaynak bağımlılığı teorisinin her biri gücün ilgili kaynakları kontrol etmeyle elde edilebileceğini varsaymaktadır. Bu varsayım da bağımlılık-güç ilişkisini en iyi şekilde ifade etmektedir. Güç sabit, durağan ya da mutlak olmadığından dolayı insanlar sürekli olarak bu gücünü artırarak egemen durumda olmak isterler. Bu ihtiyacı karşılayabilmek için de çeşitli taktikler geliştirirler. Thibaut ve Kelley (1959: 120-122) gücün bağımlılık ilişkisinden kaynaklandığı durumlarda A kişisinin B kişisi karşısındaki gücünü aşağıdaki şekillerde attırabileceğini ifade etmektedir; 
- A alternatiflerini geliştirebilir,

- B'nin alternatifleri azaltılabilir,

- A, B’yi kendine bağımlı kılacak yeteneklerini geliştirebilir,

- B'nin becerileri azaltılabilir,

- Propaganda ile A'nın yaptıkları değerli hale getirilebilir,

- B’nin yaptıkları değersizleştirilebilir,

- A zaman perspektifini uzatabilir yani bazı ihtiyaçlarını erteleyerek B'ye olan bağımlılığını azaltabilir.

\subsubsection{Güç-İktidar İlişkisi}

Güç; eski Türkçe, küç "zor, şiddet, kudret" sözcüğünden evirilmiştir (www.nisanyansozluk.com). Türk Dil Kurumu ise gücü birinci anlamında; fiziksel, düşünsel ve ahlâksal bir etki yapabilme ya da bir etkiye direnebilme yeteneği olarak tanımlarken ikinci anlamında; bir olaya yol açan her türlü hareket, kuvvet, takat (www.tdk.gov.tr)

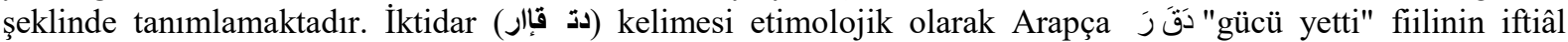
vezninde (VIII) mastarıdır. "Kudretli olma, gücü yeter olma anlamlarına gelir (www.nisanyansozluk.com). Türk Dil Kurumuna göre ise iktidar; bir işi başarabilme yetki ve yeteneği, diğer bir anlamda bu yetkiyi kullanan kişiyi ifade etmektedir (www.tdk.gov.tr). Hükümeti yönetenler anlamında kullanılan iktidar Arapça kudret kökünden türetilmiştir (Hançerlioğlu, 1996: 193).

Arapçada kullanılan kuvve (قُوَّة) Türkçedeki güç ile aynı anlamdadır. Fakat İngilizcedeki kuvvet (force) ile karıştırılmamalıdır (Hançerlioğlu, 2010: 149). Arapça kuvve; güç, kabiliyet, yetenek demektir (Devellioğlu, 1993: 531; Parlatır, 2011: 943). İktidar ise gadera (دقَ) fiilinden gelmektedir ve gücü yetme anlamındadır (Devellioğlu, 1993: 425). Bir işi yapabilme yetkisi, gücü yetme, kudret ve devlet yönetimini elinde bulundurma anlamlarına gelir (Parlatır, 2011: 719). Arapça kasıt ve ihtiyar (tercih ederek) ile fiil işleyen anlamına gelen kâdir (Cürcânî, 1997: 177) ile aynı kökten gelmektedir. Yani iktidar kelimesinde yapılan eylemin farkında olmak, kasten yapmak anlamları vardır. Fakat literatür incelendiğinde (özellikle batı menşeli kaynaklar ve Türkçe çeviri kaynaklar) genellikle güç ile iktidar aynı anlamda kullanılmışıtır. Örneğin Marshall (1999: 287) tarafından yazılan Sosyoloji Sözlüğünde güç kavramının karşıllı̆ında "bkz. iktidar" ibaresi yer almaktadır. Yine İngilizceden Türkçeye çevrilen Canetti'nin Kitle ve İktidar kitabının İngilizcesi Crowds and Power, Almancası Masse und Macht olmasına rağmen Kitle ve İktidar olarak Türkçeye çevrilmiştir. İktidar ile güç aynı şeymiş gibi kullanılmasına karşın, bir çelişkidir ki kitabın içerisinde (sayfa 283) güç ve iktidar farkı anlatılmaya çalışılmıştır. Hâlbuki Weber Macht kavramını güç anlamında kullanmaktaydı. Belki bu kavram kargaşasının sebebi disiplinler arası farklılıklardır. Çünkü genellikle "power" işletmecilik literatüründe güç anlamında kullanılırken; sosyoloji ya da kamu yönetimi gibi alanlarda iktidar olarak kullanılmaktadır. Özellikle çeviri kitapların birçoğunda bu kavram kargaşası mevcuttur

Gücü işleri başarabilmek için insanları ve kaynakları seferber edebilme kapasitesi olarak tanımlayan Kanter; böyle bir tanımla gücün kontrol ya da egemenlikten daha ziyade kapasite ve etkinlik anlamına geldiğini (Kanter, 1981: 221) ifade etmektedir. Egemenlik ve kontrol ise daha çok "iktidar" kavramını çağrıştırmaktadır. İnsan ve Toplum Bilimleri Sözlüğ̈̈nde Seyyar (2007: 441) iktidarı; toplumu yönetme, yönlendirme gücünü elinde bulunduran organ şeklinde tanımlamaktadır.

İki kişi arasındaki iktidar anlayışı düşünüldüğünde iktidar; bir kişinin iradesinin diğer bir kişiye üstün olmasıdır (Sennet, 2011: 172). Güç daha çok bir - ebilme potansiyeliyken iktidar başka bir öğeyi düzenleme, denetleme anlamlarına gelmektedir (Gümüş, 2011: 76). Yani iktidar hâkimiyet, egemenlik gibi kavramları çağrıştırırken güç; yöneltme, yetenek, kapasite kavramlarını çağrıştırmaktadır.

Yukarıda genel anlamda güç incelenerek çeşitli kavramlarla olan ilişkisi ortaya konulmaya çalışılmıştır. Gücün otorite-etki-uyma-bağımlılık-iktidar gibi kavramlarla olan ilişkisinin anlaşılması kavramsal açıdan gücün anlaşılmasını kolaylaştıracaktır. Fakat bir olgu olarak daha iyi anlaşılması gücün kaynaklarının ve sonuçlarının neler olduğunun, güce karşı verilen tepkilerin neler olduğunun anlaşılmasını zorunlu kılmaktadır. Çünkü bir olgu tüm yönleriyle anlaşılmak istendiğinde kavramı netleştirebilmek için benzer kavramlardan ayırmak, olguyu ortaya kayabilmek için süreci sebep ve sonuçlarıyla birlikte tahlil etmek gerekir. Bu gereklilikten dolayı aşağıda güç kaynakları ve güce karşı geliştirilen tepkiler incelenecektir. 


\subsection{Güç Kaynakları}

Özünde başkalarının davranışlarını etkileme (manipüle etme, yönlendirme vb.) olan güç olgusu bu görevini (davranışları etkileme) yerine getirebilmek için çeşitli kaynaklardan beslenmektedir. Çünkü meydana gelen her şeyin bir kaynağı, güç aldığı bir dayanağının olması zorunluluktur. Rekabet ortamının hâkim olduğu örgütlerde de bireyler, bu kaynaklardan beslenerek güç elde ederler. Literatür incelendiğinde başkalarını etkileyebilmek için kendisinden faydalanılan güç kaynaklarının çeşitli şekillerde sınıflandırıldığı görülmektedir (Robbins and Judge, 2011; Jones, 2010; Daft et al., 2010; Morgan, 2006; Can vd., 2006; Bolman and Deal, 2003; Brass, 2002; Mintzberg, 1983; Etzioni, 1975; Carzo and Yanouzas, 1967; French and Raven, 1959).

Jones (2010: 420) ve Wilson (1999: 123) organizasyonel güç kaynaklarını; otorite, kaynaklar üzerinde kontrol, bilginin kontrolü, yerine konulamazlık, merkezilik, belirsizliklerin kontrolü, dikkat çekmeyen güç şeklinde ifade etmiştir. Can ve diğerleri (2006: 274-276) ise güç kaynaklarını örgüt içerisindeki yapılar açısından değerlendirerek dikey ve yatay güç kaynakları şeklinde ele almışlardır. Dikey güç kaynaklarını; biçimsel makam, örgütsel kaynaklar ve kontrolü, karar verme, bilginin kontrolü, ağ bağlantısı kurma şeklinde ifade ederlerken; yatay güç kaynaklarını ise; bağımlılık, merkezilik, yerine konulamazlık, belirsizliklerin kontrolü şeklinde sıralamışlardır. Daft ve diğerleri (2010: 551-553) yukarıda sayılan yatay güç kaynaklarına finansal kaynakları da eklemiştir.

Etzioni güç kaynaklarını üçlü bir sınıflamaya tabi tutarak bu güç kaynaklarının zorlayıcı (coercive) güç, yararcı (remunerative) ve normatif (normative) güç olduğunu ifade etmiştir (1975: 5). Etzionin güç kaynakları incelendiğinde Fernch ve Raven'in yapmış olduğu sınıflamaya benzediği görülmektedir. Etzionin'nin yaptığ1 sınıflamada zorlayıcı güç French ve Raven'in zorlayıcı gücüne, yararcı gücü, ödüllendirici gücüne ve normatif gücü özdeşim gücüne benzerlik göstermektedir. Fakat Etzioni, French ve Raven'in sınıflamasındaki uzmanlık gücü ve yasal gücü sınıflamasına dâhil etmemiştir.

Bolman ve Deal (2003: 194-195) güç kaynaklarını pozisyon gücü (otorite), malumat ve uzmanlık gücü, ödüllerin kontrolü, zorlayıcı güç, ittifak ve netvork, gündeme erişme ve kontrolü, çerçeveleme: anlam ve sembollerin kontrolü ve kişisel güç olmak üzere sekiz başlık olarak sınıflamıştır.

Morgan (2006: 167) gücün on dört kaynağı olduğunu ifade etmiş ve bunları şu şekilde sıralamıştır:

- Formal otorite,

- Kit kaynakların kontrolü,

- Organizasyonel yapı, kural ve düzenlemelerinin kullanımı,

- Karar sürecinin kontrolü,

- Malumat (information) ve bilginin (knowledge) kontrolü,

- Sinırların kontrolü,

- Belirsizliklerle baş edebilme yeteneği,

- Teknolojinin kontrolü,

- Kişilerarası ittifaklar, netvörk ve informal yapıların kontrolü,

- Karşıt organizasyonların kontrolü,

- Sembolizm ve maksatların yönetimi,

- Toplumsal cinsiyet ve toplumsal cinsiyet ilişkilerinin yönetimi,

- Eylem alanını belirleyen yapısal faktörler,

- Sahip olunan güç.

Mintzberg (1983: 24) gücün beş kaynağı olduğunu belirterek bunları; kaynakların kontrolü, teknik beceri, bilgi birikimi, yasal imtiyazlar ve bu dört kaynağa erişim olarak sıralamıştır. Mitzberg'e göre ilk üç kaynak bir organizasyon için kritik rol oynamaktadır. O yüzden de bu üç durumun temel güç kaynağı olduğunu ifade etmektedir. Kaynakların, beceri ve bilgi birikimin güç kaynağı olarak işlevini yerine getirebilmesi için kıt, ikame edilemez ve organizasyonun işleyişi için temel teşkil etmesi gerekir. 
Carzo ve Yanouzas (1967:198) ise güç kaynaklarının çok çeşitli olduğunu fakat özellikler açısından değerlendirildiğinde organizasyon nitelikleri, kişisel nitelikler ve grup nitelikleri şeklinde bir sınıflama yapılması gerektiğini ifade etmiştir. Organizasyon nitelikleri arasında yönetim hiyerarşisindeki formal pozisyon ve otorite, işin önemi ve konum (kişinin bilgi akışının olduğu stratejik noktalarda olması, organizasyonel bileşenler arasında olması gibi) sayılabilir. Kişisel nitelikler: uzmanlık, ilgi, görev süresi ve kişisel özellikler; grup nitelikleri ise informal örgütlenme ve koalisyonlardır.

Gücü “sosyal güç” olarak tanımlayan French ve Raven (1959: 156) gücün; B’nin kendisi için A'nın ödüllere aracılık etme (ödüllendirme) yeteneğinin olduğu algısına dayanan ödül gücü, B'nin kendisi için A'nın cezalara aracılık etme (cezalandırma) yeteneğinin olduğu algısına dayanan zorlayıcı güç, B'nin A tarafından kendi davranışlarının belirlenmesi (tayin edilmesi) için A'nın yasal hakkı olduğu algısına dayanan yasal güç, B'nin kendini A ile özdeşleştirmesine dayanan özdeşim gücü, A’nın bazı özel bilgi ve uzmanlıklara sahip olduğu algısına dayanan uzmanlık gücü olmak üzere beş kaynağı olduğunu ifade etmişlerdir. Raven (1965) bu güç kaynaklarına iletişimin içeriğinden kaynaklanan ve etki edenden bağımsız, etkilenende bilişsel değişime neden olan malumat gücünü de ekleyerek güç kaynağını altıya çıkarmıştır.

Raven yukarıdaki güç kaynakları sınıflamasını daha derinlemesine inceleyerek detaylandırdığı çalışmalarında yasal gücü; pozisyondan kaynaklı yasal güç, yasal karşılık gücü, yasal eşitlik gücü, yasal bağımlılık gücü şeklinde; ödül ve zorlayıcı gücün her ikisini de kişisel ve kişisel olmayan şeklinde; uzmanlık ve özdeşim gücünü pozitif ve negatif şeklinde; malumat gücünü ise direkt ve endirekt şeklinde bir sınıflamaya tabi tutmuştur (Raven, 1993: 235; Raven, et al., 1998: 310).

Wong 2003 yılında yapmış olduğu çalışmasında French ile Raven (1959) ve Raven'in (1965) yapmış olduğu toplam altı güç kaynağına daha sonra Hersey ve diğerleri (2001), Yukl (1989) ve Bass (1998) tarafindan eklemeler yapıldığını belirtmektedir. Örgütün çerisinde ve dışında bulunan önemli ve güçlü kişilerle kurulan bağlantıya dayalı bağlantı gücü, bürokratik kontrol ve politik manevralarla gücü sürdürme ve muhalefeti zayıflatma yeteneğine dayanan politik güç, çalışanların ellerinden gelenin en iyisini yapmaları için ilham verme yeteneğine dayanan ilham verici güç ve son olarak kişinin karakteri, cesareti ve dürüstlüğü ile örgütün iklimini ve yönünü değiştirebilme yeteneğine dayanan dönüştürücü güç yeni eklenen güç kaynaklarıdır (Wong, 2003: 3).

Robbins ve Judge (2011: 414-415) ise French ve Raven'in güç kaynaklarını (ödül, zorlayıcı, yasal, özdeşim ve uzmanlık gücü) formal güç kaynakları ve kişisel güç kaynakları olmak üzere iki genel grupta incelemişlerdir. Formal güç kaynakları ödül gücü, zorlayıcı güç ve yasal güç kaynaklarından; kişisel güç kaynakları ise özdeşim gücü ve uzmanlık gücünden oluşmaktadır. Yine Rahim (1988: 497) French ve Raven'in güç kaynaklarını faktör analizine tabi tutarak iki temel boyutta değerlendirmiş ve bunları kişisel ve pozisyona bağlı güç kaynakları olarak isimlendirmiştir. Pozisyon boyutunu yasal, ödül ve ceza gücü oluştururken, kişisel boyutu ise uzmanlık ve özdeşim gücü oluşturmaktadır.

French ve Raven'in literatüre kazandırdığı beş güç kaynağı organizasyonla ilgili güç kaynakları ve kişiyle ilgili güç kaynakları olmak üzere iki kategoride ifade edilebilir. Organizasyonla ilgili güç kaynakları kişinin organizasyondaki pozisyonuna bağlı olarak elde ettiği güç kaynakları olan yasal güç, ödül gücü ve zorlayıcı güçtür. Bunlar kişinin görev tanımı değiştiğinde değişebilecek güç kaynaklarıdır. Kişisel güç kaynakları ise uzmanlık ve özdeşim gücüdür. Bunlar organizasyondan bağımsız olarak kişide bulunurlar (Gibson et al., 1991: 333; Northcraft and Neale, 1990: 331; Newstrom and Davis, 1997: 328).

Buraya kadar ifade edilenlerden literatürde güç kaynaklarının çeşitli sınıflandırmalarının (Carzo and Yanouzas, 1967; Etzioni, 1975; Mintzberg, 1983) yapılmış olduğu görülmektedir. Her ne kadar çeşitli yazarlar tarafindan (Kipniset al., 1980; Hinkin and Schriesheim, 1989) eleştirilse de Mintzberg (1983: 120) ve Cobb (1980: 155) gibi çoğu düşünür French ve Raven'nin beşli taksonomisinin literatürde en çok kullanılan sınıflama olduğunu vurgulamaktadır. Rahim ve Psenicka'nın (1996: 32) ifadesiyle; French ve Raven tarafından yapılan beşli ayrım uygulamada hâlâ kabul gören popüler bir sınıflamadır. Günümüzde de çok bir şeyin değişmediği, bu sınıflamanın hâlâ önemini koruduğu görülmektedir. Ders materyalleri ya da son zamanlarda yapılan çalışmalar (Özaslan ve Gürsel, 2008; Altınkurt vd., 2014) incelendiğinde bu taksonominin hâlâ en çok kullanılan sınıflama olduğu görülmektedir.

\subsubsection{Güç Kaynaklarının Birbirleriyle İlişkisi}

Beş güç kaynağı arasında anlamlı derecede karşılıklı ilişki vardır (Rahim, 2004: 5). Greene ve Podsakoff (1981: 534) yapmış oldukları çalışmada ödül gücü ile özdeşim gücü, uzmanlık gücü ve yasal güç arasında; zorlayıcı güç 
ile yasal güç arasında; özdeşim gücü ile uzmanlık gücü arasında; uzmanlık gücü ile yasal güç arasında pozitif yönlü; zorlayıcı güç ile özdeşim gücü arasında ise negatif yönlü bir ilişki olduğunu bulmuşlardır. French ve Raven (1959: 157) A’nın B’ye karşı vaatler yerine gerçek ödüller kullanmasının zamanla B’nin A'ya karşı sempati duymasına neden olacağını, bu durumun da A'nın B üzerindeki özdeşim gücünü ortaya çıkaracağını belirtmektedir. French ve diğerlerine göre zorlayıcı güç A’nın B’ye sempati duyma eğilimini azaltacaktır (Akt. French and Raven, 1959: 157).

Munduate ve Dorado (1998: 178) yapmış oldukları çalışmada ödül gücü ile zorlayıcı güç arasında; yasal güçle zorlayıcı güç ve ödül gücü arasında; uzmanlık gücüyle yasal güç arasında; benzeşim gücüyle zorlayıcı güç, yasal güç, uzmanlık gücü ve ödül gücü arasında pozitif yönde anlamlı bir ilişki bulmuşlardır.

Güç tarzlarının algılanışı kültürden kültüre değişebildiği gibi birbiri arasındaki ilişkiler de kültürden kültüre değişebilmektedir. Rahim (2004: 34) Amerika, Güney Kore, Yunanistan ve Bangladeş’ten topladığı verilerle French ve Raven'in (1959) güç kaynaklarını (yasal, zorlayıcı, ödül, uzmanlık benzeşim gücü) kültürel açıdan değerlendirmiştir. Çalışma sonucunda Amerikan kültüründe yasal güçle uzmanlık gücü ve özdeşim gücü arasında, uzmanlık gücü ile özdeşim gücü arasında, ödül gücü ile uzmanlık gücü arasında pozitif; zorlayıcı güç ile uzmanlık gücü arasında negatif yönde anlamlı bir ilişki bulunmuştur. Yunan kültüründe ise ödül gücü ile uzmanlık ve özdeşim gücü arasında, yasal güçle uzmanlık gücü arasında, uzmanlık gücü ile özdeşim gücü arasında pozitif yönde anlamlı bir ilişki bulunmuştur. Güney Kore ile ilgili ise ödül gücü ile uzmanlık gücü arasında, yasal güçle uzmanlık gücü arasında, uzmanlık gücüyle özdeşim gücü arasında pozitif yönde anlamlı bir ilişki bulunmuştur. Son olarak Bangladeş'le ilgili bulgulara bakıldığında ödül gücü ile uzmanlık ve özdeşim gücü, yasal güçle uzmanlık gücü, uzmanlık gücüyle özdeşim gücü arasında pozitif yönde anlamlı bir ilişki bulunmuştur.

Meydan ve Polat'ın (2010) ise yapmış oldukları iki aşamalı çalışmada önce atasözleri içerik analizine tabi tutulmuş sonrasında ise Türkiye'de orta kademe yöneticiler üzerine görgül bir araştırma yapmışlardır. Atasözleriyle yapılan içerik analizi sonrasında meşru güç ve uzmanlık gücünün ön plana çıktığını, benzeşim ve ödüllendirme gücünün görece geri planda kaldığını, zorlayıcı güce ise çok az değinilmiş olduğunu bulgulamışlardır. Çalışmanın ikinci kısmında, orta kademe çalışanların yasal, zorlayıcı ve ödüllendirme gücü alg1 düzeylerinin ortalama güç alg1 değerinin anlamlı olarak üzerinde olduğu bulunmuştur. Kültürel olarak her iki çalışmada da yasal gücün öne çıktığı görülmüştür.

Genel anlamda, bazen pozitif yönlü bazen negatif yönlü olsa da, güç kaynakları arasında bir ilişki olduğu görülmektedir. Bir güç kaynağının güçlü/zayıf olması zamanla başka bir güç kaynağının güçlenmesine/zayıflamasına sebep olabilmektedir. Örneğin ödül gücü yüksek birinin zamanla ceza gücünü kullanımı azalacaktır. Aynı şekilde ödül gücü kendine sempati beslenmesini sağlayarak özdeşim gücünü artırabilecektir. Yine uzmanlık gücü zamanla özdeşim gücünü artırabilecektir.

\subsection{Güce Karşı Tepkiler}

Güce karşı genellikle mutabakat, itaat etme ve direnme olmak üzere üç tepkiden söz edilmektedir. Mutabakat failin görüşünün hedef tarafından paylaşılmasını ve istekli bir şekilde talimatlarının uygulandığı durumları ifade eder. Uzmanlık ve özdeşim gücü hedef tarafından mutabakat ile sonuçlanır. İtaat ise, hedefin isteksiz olmasına ve verilen talimatlara katılmamasına rağmen kurallara uyması ve talimatları yerine getirmesi durumunu ifade eder. Yasal güç ve ödül gücü itaat ile sonuçlanır. Son olarak direnç ise; hedefin kasıtlı olarak talimatlardan kaçınması ve kurallara itaatsizlik etmeye çalışması durumunu ifade eder. Zorlayıcı güç genellikle direnme ile sonuçlanacaktır (Yukl ve Taber 1983'den Akt. Daft, 1991: 373; Newstrom and David, 1997: 328).

Griffin ve Moorhead (2013: 382) Organizational Behavior: Managing People and Organization adl1 eserlerinde French ve Raven tarafindan yapılan güç kaynağı sınıflamasını mutabakat, itaat etme ve direnç açısından değerlendirmişlerdir. Dorwin P. Cartwright (1959)'ın editörlüğünü yaptığı Studies in Social Power adlı eserden esinlenerek Griffin ve Moorhead'in oluşturduğu güç kaynakları ve bunlara verilen tepkiler sınıflaması Tablo 1.'de gösterimektedir. 
Süleyman Demirel Üniversitesi Vizyoner Dergisi, Yıl: 2019, Cilt: 10, Sayı: 24, ss.405-433.

Suleyman Demirel University Visionary Journal, Year: 2019, Volume: 10, Number: 24, pp.405-433.

Tablo 1. Güç Kaynaklarının Kullanımı ve Verilen Tepkiler

\begin{tabular}{|l|l|l|l|}
\hline \multirow{2}{*}{ Güç Kaynakları } & \multicolumn{3}{|c|}{ Tepkiler } \\
\cline { 2 - 4 } & Mutabakat & İtaat & Direnme \\
\hline Özdeşim Gücü & Büyük ihtimalle & Olabilir & Olabilir \\
\hline Uzmanlık Gücü & Büyük ihtimalle & Olabilir & Olabilir \\
\hline Yasal Güç & Olabilir & Büyük ihtimalle & Olabilir \\
\hline Ödül Gücü & Olabilir & Büyük ihtimalle & Olabilir \\
\hline Zorlayıcı Güç & Kesinlikle olmaz & Olabilir & Büyük ihtimalle \\
\hline
\end{tabular}

Kaynak: (Griffin ve Moorhead, 2013: 382).

Tablo 1.'den de anlaşılacağı gibi, hedef tarafından özdeşim gücü ve uzmanlık gücü büyük ihtimalle mutabakatla karşılanacaktır. Yasal güç ile ödül gücünün mutabakatla karşılanması ihtimali olsa da zorlayıcı güç kesinlikle mutabakatla karşılaşmayacaktır. İtaat açısından bakıldığında ise yasal güç ve ödül gücünün büyük ihtimalle itaatle sonuçlanması beklenirken; özdeşim, uzmanlık ve zorlayıcı gücün itaatle sonuçlanması ihtimal dâhilindedir, olmama ihtimali de vardır. Zorlayıcı güç büyük ihtimalle dirençle karşılaşacaktır. Diğer dört güç kaynağının ise dirençle karşılaşma ihtimalinin olduğu gibi karşılaşmama ihtimali de vardır.

Buraya kadar olan kısımda güç kavramsal olarak incelenmiş, diğer kavramlarla olan ilişkileri ortaya konulmaya çalışılmıştır. Ayrıca literatürdeki güç kaynaklarına değinilerek birbirleriyle olan ilişkileri ve güce karşı verilen tepkiler ortaya konulmaya çalışılmıştır. Yapılan incelemede güç kaynaklarının çeşitli şekillerde sınıflandırıldığı görülmüştür. Fakat sınıflandırmalar incelendiğinde birçoğunun aynı duruma farklı açılardan bakmakla yapılmış sınıflamalar olduğu, bazı sınıflandırmaların diğerlerinden tamamen farklı olduğu görülmektedir. Her ne kadar çok sayıda sınıflama yapılsa da bu durum başka güç kaynaklarının belirlenemeyeceği anlamına gelmemektedir. Çünkü yapılan sınıflandırmalar kendi içerisinde tekrar sınıflandırmaya tabi tutulsa baz alınan kategori türüne göre farklılıklar arz ettiği görülecektir. Bunun yanında literatüre bakıldığında gerek kavramsallaştırma açısından gerekse gücün kaynakları açısından informal güç kavramına çok fazla değinilmediği görülecektir. Bu minvalde informal gücün de incelenmesi güç konusunun daha iyi anlaşılabilmesi için önem arz etmektedir. Çünkü deruni bilgilerin derinlemesine incelemenin neticesinde elde edileceği düşünülmektedir.

\section{INFORMAL GÜÇ}

Varlığını inkâr edemeyeceğimiz güç ilişkilerinin süreklilik arz eden bir durum olduğu herkes tarafindan bilinmektedir. Canlıların doğasında var olan egemenlik, üstünlük kurma, itaat ettirme, fikirlerini kabul ettirme ve yönlendirme duygusu güç ilişkilerini ortaya çıkarmaktadır. Örgütler açısından bakıldığında da güç ilişkileri kaçınılmaz bir durumdur. Derinlemesine göz atıldığında pratikte bu ilişkilerin çeşitli şekillerde tezahür ettiği görülmektedir. Kimi zaman bir amirin yasal gücünü kullanarak bir şeyleri yaptırmasında ortaya çıkabildiği gibi bazen de kişisel bağlantılarını kullanarak bir iş yaptırmasında tezahür edebilmektedir. Ya da bazen tehdit ve zorlama potansiyelinde hayat bulabildiği gibi bazen de karizmanın kullanılmasında kendini gerçekleştirebilmektedir. Diğer alanlardaki güç ilişkileri örgütlerde güç olgusuna dönüşmektedir. Çünkü örgütlerin hayatiyetine devam edebilmesi yöneticinin güç ilişkilerini nasıl yönettiğine bağlıdır.

İnsanlar arası etkileşimde, ne şekilde olursa olsun sürekli bir güç ilişkisi mevcuttur. İlk bakışta bu ilişkilerin resmi yapılardan kaynaklanan formal (biçimsel, resmi) ilişkiler olduğu düşünülecektir. Fakat olaylara daha üst pencereden bakıldığında aslında ilişkilerin informalite kavramının üzerine bina edildiği görülecektir. Çünkü formal ile informal insanın bedeni ve ruhu gibidir. Beden somuttur, duyu organları aracılığıyla varlığına şahit olunabilir, görülür, hissedilir. Ancak ruh ise; soyuttur, duyu organlarımızla test edilemez sadece varlığ İçinden ruhu çıkan cesedin anlamsızlaştığı gibi bilinen olmadan görünen anlamsızlaşıverir. Bu noktadan hareketle güç konusuna informal açıdan da bakılması zorunluluk teşkil etmektedir. Bu zorunluluktaki etkenlerden birincisi doğadan bir örnekle daha iyi fark edilecektir. Doğanın bir parçası olan kuşlar ele alındığında hepsinin iki kanatlı olduğu görülecektir. Eğer kanadının biri kırıldıysa artık semalarda değildir, uçma yetisini kaybetmiştir. O yüzden; tıpkı tek kanadı olmayan kuşun uçamayacağı gibi tek tarafı bilinen güç kavramının da tam manasıyla anlaşılamayacağı düşünülmektedir. Güç kavramına informal açıdan bakılmasındaki zorunluluklardan ikincisi ise literatürün gücün informal yönünü ihmal etmiş olmasıdır. Tüm bu sebeplerden dolayı bu bölümde gücün informal (biçimsel olmayan, doğal) kısmı ele alınacaktır. 


\section{1. İnformalite}

Örgütler formal olarak tanımlanan pozisyonlar ve informal davranışların toplamından oluşan (Brass, 1984: 519) kurumlar olması sebebiyle formal ve informal yapılardan oluşmaktadır. Bünyesinde barındırdığı ikili yapı örgütleri karmaşık ilişkilerin yaşandığı kurumlara dönüştürmektedir. Örgütlerin başarısı ise bu karmaşık ilişkilerin iyi bir şekilde dizayn edilerek, doğru kanalize edilmesi ve örgütün amaçları bağlamında yönetilmesine bağlıdır. İlişkilerin çözümlenmesi ve bu ilişkilerden neşet edecek sonuçların örgütün yararına olacak şekilde yönetilebilmesi ise buzdağının görünmeyen yüzünün yani örgütlerdeki informalitenin tam anlamıyla anlaşılmasını gerektirmektedir. Bu bağlamda örgüt yapılarının incelenmesi de önem arz etmektedir.

Erdem ve diğerleri (2017: 5) örgütlerde formal ve informal yapı ile ilgili yapmış oldukları tanımlamada formaliteyi; daha önceden kazanılmış (tecrübe ya da öğrenme yoluyla) bilgiler sayesinde herhangi bir organizasyonda rasyonalite süzgecinden geçirilerek düzenlenmiş ve yazılı hale gelmiş kurallar, prosedürler, tavır ve davranışlar olarak tanımlarken bu kural, prosedür, tavır ve davranışların hakim olduğu örgüt yapılarının da formal yapıyı oluşturduğunu belirtmişlerdir. İnformalite ise çoğu zaman kendiliğinden oluşan, insan olmanın sonucu olarak gelişen sevgi, nefret, gibi duyguların hâkim olduğu; düzenlenmemiş, yazılı hale gelmemiş ve daha çok derinliğe sahip olduğundan dolayı kolayca fark edilemeyen işleyiş, tavır ve davranış biçimleridir. İnformal yapı bu tavır ve davranışları bünyesinde barındıran, formal yapıdan kaynaklanan boşlukları dolduran örtük örgütlenmeler şeklinde tanımlanmıştır. Erdem ve diğerleri düzenlenmemiş olduğunu ifade etseler de informal tavır ve davranışların da bir kısmı informal grupların kendi aralarındaki söz birlikleri ile düzenlenmiş ve sözlü kurallara bağlanmıştır. Hatta informal yapıların içerisinde formal yapılar, formal yapıların içerisinde de informal yapilar mevcuttur.

Yücel ve Erkut (2003: 50) ise informal yapıları bilinçli bir tasarım söz konusu olmadan, kendiliğinden ortaya çıkan ilişkilerin ifade ettiği, ön görülemeyen, çalışanların birbirleriyle ilişkisinden doğan yapılar şeklinde tanımlayarak inanç, fikirler, his ve kültür gibi olguların bu yapının altında değerlendirilebileceğini belirtmektedir. Gürol ve Turhan (2005: 86) ise informal yapıları; informal gruplar, iş harici ilişkiler gibi kendiliğinden oluşan ve örgütün doğal yönüne işaret eden yapılar şeklinde ifade etmektedir. Örgütteki informal yapı anlayışı ve yapı içerisindeki ilişkilerin ahenkleştirilmesini gerektirir. Durukan (2003: 284) örgütteki formal yapının hiyerarşi, yetki, emir ve kontrol gibi kavramlar sayesinde sürdürülebileceğini, informal yapıların ise grup davranışlarının çözümlenmesi, bireylerin ihtiyaçlarının belirlenmesi ve güdüleme gibi yöntemlerle yönetilebileceğini ifade etmektedir. İki yapı (formal ve informal) yönetimsel açıdan değerlendirildiğinde ise canlılığı/dinamizmi sağlayan tarafin informal yapılar olduğu vurgulanmaktadır.

Formal ve informal birbirinin tamamlayıcısı şeklinde tasavvur edilebilecek iki kavramdır. Yani biri olmadan diğeri hep eksik kalacaktır. Bu noktada Erdem ve diğerlerinin formal ve informal ilişkisini anlatmak için kullandıkları tohum-bitki metaforu kavramlar arasındaki bağ sarmalını açıklayıcı olacaktır. Ağaç ya da bitkinin toprağın yüzeyinde görülen kısmı her ne kadar formaliteyi simgelese de toprağın altında kalan tohum ya da bitkinin kökü informaliteyi temsil etmektedir. Toprağın altındadır, görünmez ama uygun şartlar oluşunca neşvünema bularak toprak yüzeyine çıkacaktır. Toprak yüzeyine çıkınca ya formal düzen tarafından varlığı kabul edilerek ona göre düzenlemeler yapılacak ya da formal düzen tarafından kesilerek yok edilecektir. Yani esasında bütün formal düzenlerin beslendiği bir informal kökenin olduğu söylenebilir. Bu açıdan bakıldığında herhangi bir şeyin informalliği kuluçka dönemi olarak düşünülebilir (Erdem vd., 2017: 5). Hatta bir adım sonrası düşünüldüğünde ağaçtaki meyve olgunlaşıp yere düşecek ve tohumu toprağa karışarak yeniden neşvünema bulacaktır. Bu açıdan değerlendirildiğinde, aslında formalite ve informalite kavramları birbirinin karşıtı değil bilakis birbirlerini besleyen iki kavram olarak ele alınabilirler.

O halde örgütlerde informalite; örgütün hiyerarşik yapısındaki kurallardan bağımsız olarak doğal/kendiliğinden gelişen fakat yönetilebilme becerisine bağlı olarak örgütün amaçlarına ulaşmasını sağlama ya da örgütü alaşağı ederek yok olmasına sebep olma potansiyeline sahip olan; tanımlanmamış, yazılı hale getirilmemiş, insan olmanın gereği olan ihtiyaçlardan ortaya çıkan ilişkiler ağı ya da tavır ve davranışlar bütünü olarak tanımlanabilecektir. Örgüt içerisinde informalite; informal gruplar, informal yapılar, informal iletişim, informal ilişkiler, informal güç arayışı, informal güç gibi çeşitli şekillerde tezahür edebilen bir olgu olarak karşımıza çıkabilmektedir. $\mathrm{Bu}$ çalışmada ise informal gruplar, informal iletişim, informal ilişkiler ya da informal yapıların doğrudan ya da dolaylı olarak etkilediği informal güç konusu ele alınacaktır.

Güç ilişkilerine bakmak kimin kimi etkilediği ya da etkileme yeteneği olduğu açısından önem arz etmektedir. Güç ilişkilerinin formal mi yoksa informal mi olduğu güç ilişkilerine farklı bir bakış sunmaktadır. Güç bazen hiyerarşik 
pozisyondan gelebildiği gibi bazen de uzmanlıktan veya hayranlık uyandıran niteliklerden gelebilir (Daft, 2008: 379). Diğer taraftan değer, duygu, kişisel bağlantı ya da referans gibi kişinin kendi bireysel çabaları vasıtasıyla ya da örgüt hiyerarşisindeki pozisyonu dışındaki konumundan da gelebilmektedir.

\section{2. İnformal Güç}

Örgütlerde informal gücün varlığı herkesçe bilinen fakat bilimsel anlamda, üzerinde çok fazla durulmayan bir konudur (Yılmaz vd., 2017: 64). Güç soyut ve dinamik bir kavram olması hasebiyle üzerinde çalışma yapmak zorken bir adım daha ilerisine gidilerek konu informal güce getirildiğinde ise literatürdeki boşluğun sebebi daha iyi anlaşılacaktır. Çünkü güç kavramı tek başına bu zorluğa haizken; özünde görünmeyeni, olayların iç yüzünü, arka planını, ana nedenini barındıran informal kavramıyla birleştiğinde üzerinde fikir beyan ederek anlam birliğine varabilmek informal güç için oldukça zordur. Fakat her ne kadar meşakkatli olsa da bu zorluğu göze alıp informal güçle ilgili tanımla girişiminde bulunan yazarlar da yok değildir. Literatür incelendiğinde bazı kaynaklarda informal gücün tanımlarının yapıldı̆̆ı görülmektedir.

Labun (2012: 30) informal gücü; "bireyin kendisinin ve diğerlerinin gücünün zihinsel temsilidir” şeklinde tanımlamaktadır. Tanım geniş anlamda düşünüldüğünde informal gücü tanımlıyormuş hissi uyandırsa da dikkat edildiğinde daha çok bir tanımlama denemesi olduğu görülecektir. Çünkü içinde informaliteyi çağrıştıracak ya da ifade edecek kavramların olmamasının yanında daha çok "güç potansiyel etkidir" tanımını çağrıştırmaktadır. Esasında potansiyel olan zaten algısaldır yani karşı tarafın zihnindeki izlenimdir. George ve Jones (2011: 374-376) ise güç kaynaklarındaki pozisyon gücü ve kişisel güç ayrımından etkilenerek informal gücü, bireyin kişisel özelliklerinden kaynaklı güç olarak ifade etmektedir. George ve Jones'ın tanımı informal güce daha yaklaşmıştır. Özellikle kişinin hiyerarşik pozisyonundan kaynaklanan (formal) gücünü öteleyip formal gücü çağrıştıran bireyin kişisel özelliklerine vurgu yaparak özdeşim gücünü çağrıştırmıştır. Yani French ve Raven'in güç kaynaklarına yönelik yapmış oldukları sınıflama baz alınarak yapılmış bir tanımlama izlenimi uyandırsa da bir yönüyle informal güce değinmiştir. Finkelstein ve D’Avani (1994: 1086) informal gücü, "resmi pozisyona doğrudan bağlı olmayan kaynaklardan gelen güç" şeklindeki tanımlamalarıyla informal gücü George ve Jones gibi pozisyon (hiyerarşik) temelinde değerlendirmişlerdir. Benzer bir tanımla Thompson (2014: 26) informal gücü kişideki formal güç hiyerarşilerinin dışındaki faktörlere dayanan güç olarak; Peiró ve Meliá (2003: 17) ise kişisel yetkinliklere, geçmişe ve tecrübelere dayalı kişisel nitelikler olarak ifade ederek bir nevi yukarıdaki tanımlamayı pekiştirmişlerdir.

Hulasa; literatürde informal güç daha çok pozisyon gücü temelinde ele alınarak kişinin örgüt içerisindeki hiyerarşik konumundan kaynaklanmayarak bizatihi kendi kişisel özelliklerinden kaynaklanan güç olarak ele alınmıştır. Literatürde yapılan tanımlamalar ve gerçek yaşamda gözlenen güç ilişkileri dikkate alınarak bir informal güç tanımlama denemesi yapıldığında informal güç; daha çok kişinin hiyerarşideki pozisyonu (yetki) dışındaki kişisel özellikleri, ilişkileri, iletişimi, norm ve değerleri gibi içsel ve dışsal motivasyondan kaynaklanan, ast üst ilişkilerinin genellikle göz ardı edildiği, diğer bireyleri etkileyebilme, örgütsel ve bireysel amaçlara ulaşabilmek için diğerlerinin davranışlarını manipüle edebilme ya da yönlendirip yönetebilme yeteneği şeklinde tanımlanabilecektir. Yani A’nın; hiyerarşik pozisyonundan bağımsız olarak B'yi etkileyebilme kapasitesidir.

Yukarıdaki tanımda ast üst ilişkilerinin göz ardı edilmesi vurgusu önemlidir. Çünkü hiyerarşide daha çok üstler astlarını yönlendirme (emir-komuta) potansiyeline sahiptir. Fakat esasında astların da formal olarak sahip olmadığ ancak gerçekte sahip olduğu informal güçleri vardır. Can ve Çelikten (2000: 285) bu durumu “alt düzey personelin kendisine formal olarak verilmeyen ancak kullanılan yetkilerden ya da gerçekleştirilen bir takım eylemlerden dolayı görünmeyen güçleri vardır. Bu güçlerin kaynăğ informaldir. Örneğin özlük işlerinde çalışan bir kişinin personel için önemli işleri yürütmelerinden dolay informal güçleri vardır. Bir belgenin dosyaya geç koyulması ya da erken koyulması, bir soruşturma sürecinin yavaş işletilmesi gibi informal güç kaynaklarına sahiptir" şeklinde ifade etmektedir. Yine Bateman ve Zeithaml (1990: 485) organizasyondaki herhangi bir kişinin rütbesine bakılmaksızın güce sahip olabileceğini iddia ederek, organizasyonda en alt kademede (rütbede) bulunan bir kişinin otoriteyle ilgili yasal herhangi bir güce sahip olmadığı halde aynı kişinin özel bir yeteneği ya da uzmanlığ sayesinde organizasyonda güce sahip olabileceğini belirtmektedirler. Yani aslında otoriteden bağımsız ortaya çıkan informal gücü ima etmektedirler. Binaenaleyh kişinin yaptığı işi yapabilen nadir sayıda insan varsa ya da o işin öğrenilmesi zorlu süreçler gerektiriyorsa kişi informal güce sahiptir denilebilir. Can ve Çelikten (2000: 285) bu durumu eğer yapılan iş kolayca öğrenilebilecek bir iş olarak algılanmıyorsa bu durum kişiye informal güç kazandırır şeklinde ifade etmektedirler. 
Örgüt içerisindeki hiyerarşi açısından bakıldığında horizontal yapılarla informal güç arasında pozitif yönlü anlamlı bir ilişki olduğu (Norbom, 2009: 78) görülecektir. Bu bağlamda formal güç kullanımında mümkün olmasa da informal güç kullanımında astlar üstlerini etkileyebilecektir. Yani üstleri üzerinde informal güç sahibi olabilecektir. Fakat durum her ne kadar böyle olsa da ast-üst ile kıyaslandığında akranların birbirleri üzerinde daha fazla informal güce sahip olacağı yorumu yapılabilecektir.

Karmaşık ilişkilerin yaşandığı örgütlerde informal güç kendini daha fazla gösterecektir. Bu açıdan hastaneler göz önüne alındığında; matriks yapıda olmaları hasebiyle karmaşık ilişkilerin en çok yaşandığı yerlerden biri olma özelliğine sahiptir. Barkema ve Pennings'in ifadesinden hareketle bu ortamlarda informal güç ilişkilerinin daha fazla görüldüğü yorumu yapılabilecektir. Çünkü Barkema ve Pennings (1998: 982) stratejik olarak karmaşık durumlar/koşulların informal güç gerektireceğini ifade etmektedirler.

İnformal güç başkalarını etkileme potansiyeli olarak kullanılabildiği gibi bazı durumlarda makam mevki elde edebilmek için de informal güce başvurulabilmektedir. Yani sürekli etrafina hâkim olma dürtüsüyle hareket eden insan formal olarak elde edemediği makam ve mevkileri informal kaynaklardan beslenerek elde edebilmek için, isteğini elde ettikten sonra da gerek o pozisyonu koruyabilmek için, gerekse yeni pozisyonlar elde edebilmek için sürekli bir güç arayışı içerisine girmektedir. Bu arayış da genellikle formal kanalardan (sınav, terfi vb.) değil informal kanallardan (yaranma, koalisyon, mensubiyet) sürdürülmektedir. Özetle insanlarda sürekli bir güç arayış1 hâkimdir ve genellikle bu güç arayışı informal güç arayışı şeklinde kendini göstermektedir.

\section{3. İnformal Güç Arayışı}

Hofstede'in kültür boyutlarında ifade ettiği gibi insanlar, korkuyu anımsatmasından dolayı belirsizlikten kaçınmak isterler (Hofstede, 2001: 146). Bundan dolayı da bir gücün arkasına sığınarak bu korkudan kurtulmanın yolunu ararlar. Yine insanlar yönetme duygusunun ağır basmasından dolayı güçlü taraf olmayı, yönetilen taraf olmamayı tercih eder. Bu yüzden de fitri bir özellik olarak karşımıza çıkan güç arayışı, bazen bireylerin formal güçlerinin yeterli olmadığı, bazen de güçlerini daha da artırmak istedikleri durumlarda ya da gücü elde etme safhalarında informal güç arayışına yönelmelerini de beraberinde getirebilmektedir.

Örgütsel davranış kaynaklarında ifade edilen politik davranışlar aslında bir organizasyondaki güç elde etme taktiklerini (Eren, 2015: 394) yani bir nevi informal güç arayışını ifade etmektedir. Mitzberg (1983: 5) politikayı gücün alt kümesi ve bu alt kümeyi informal güç olarak gördügünü belirtmektedir. Güney’e (2011:253) göre politik davranış; kişilerin örgütsel yapı içerisindeki resmi rollerinin gerektirmediği fakat örgüt içerisindeki avantaj ve dezavantajların dağılımını etkileyen ya da etkilemeye çalışan tutum ve davranışlardır. Farrell ve Petersen (1982: 405) ise örgütlerdeki politik davranışı; kişinin örgütsel rolünün bir parçası olmadığı halde örgüt içerisindeki avantaj ve dezavantajların dağılımını etkilemeye yönelik faaliyetler olarak tanımlamaktadır.

Ezcümle, politik davranışlar kişinin güç elde edebilmek ya da var olan gücünü artırabilmek için başvurduğu çeşitli tavır ve davranışları ifade etmektedir. Bu tavır ve davranışlar yasal dayanaklarla değil de kişinin çeşitli özelliklerini kullanarak geliştirdiği taktikleri ifade ediyorsa informal güçten söz ediliyor demektir. Güney (2011: 253) gizlilik, gizlilik ihlali, dürüst davranmama ve kandırma gibi davranışları bünyesinde barındıran politik davranışların genellikle insanların statülerini yükseltebilmek için güç arayışına girmeleri ile ortaya çıkacağını dile getirmektedir. Robbins ve Judge (2011: 424) bu politik davranışları; karar vericilerden önemli malumatların saklanması, koalisyon kurma, fısıltı gazetesi, dedikodu, gizli bilgilerin medyaya sızdırılması, karşılıklı faydaya dayalı olarak sosyal alışveriş (bilgi, malumat, vb.) ve lobi faaliyetleri olarak sıralamıştır.

Erol Eren'in (2015: 394) Yönetim ve Organizasyon isimli kitabında yer verdiği DuBrin'e göre yöneticilerin güç artırmada başvurabilecekleri politikalar, örgütte diğer çalışanlar için de düşünülebilir. Bu minvalde DuBrin'in görüşleri sadece yöneticiler açısından değil ast, üst ve iş arkadaşları açısından düşünülerek revize edildiğinde güç mücadelelerinde kullanılan taktiklerin bazılarına değinilmiş olacaktır. Bu taktikler şu şekilde sıralanabilir:

- Daha güçlü kişiler ile dostluk ve iş ilişkileri kurma sayesinde netvörkünü genişletmek,

- Farklı görüşlere sahip kişilerin görüşlerini benimseyerek yandaş toplama,

- Gizli ve önemli bilgileri elinde tutarak ikame edilemezliğini artırma,

- Başkalarına yardım ederek karşılıklılık ilkesi gereği onlardan da yardım beklediğini ima ederek onları minnet altında birakma, 
- Kontrollü bir şekilde durumun kötüye gitmesine müsaade ederek, sonra durumu düzelterek üstlerinin gözüne girme.

Hirschman'ın 1970 yılında ele aldığı örgüt içi politik davranışlardan sayılan ses Kolarska ve Aldrich (1980: 44) tarafından "örgüt içerisindeki bireylerin doğrudan ya da dolaylı olarak, örgüt içinden ya da dışarıdan yetkililere memnuniyetsizliklerini ifade eden kişiler" şeklinde tanımlanarak ikiye ayrılmıştır. Doğrudan ses mağduriyetin kurum içerisindeki bir yetkiliye iletilmesi, dolaylı ses ise mağduriyetin örgüt dışından bir otoriteye iletilmesi durumudur. $\mathrm{Bu}$ durum informal güç açısından düşünüldüğünde, bireyler üstlerini daha üste ya da dişarıdan otoritelere şikâyet etme tehdidiyle örgüt içerisinde informal güç elde edebileceklerdir.

Farrell ve Petersen (1982: 405-407) politik davranışları içsel-dışsal, dikey-yatay ve yasal-yasal olmayan şeklinde üçlü bir ayrıma tabi tutmuşlardır. Bilgi uçurma, dava açma, medyaya bilgi sızdırma, örgüt dışındaki bireylerle ittifak kurma gibi davranışlar içsel-dışsal politik davranışları; komuta zincirini atlama, bir üste şikâyette bulunma (meslektaşı hakkında), üste övgü, usta-çırak ilişkisi dikey politik davranışları; emsallerle koalisyon kurma, emsallere yardımda bulunma gibi davranışlar ise yatay politik davranışlar içerir. Büyük örgütlerde orta düzey yöneticiler dikey politik davranışlar uygulama eğilimindedir. Yasal politik davranışlar görüşme, üstlerden destek arama ve koalisyon oluşturma gibi içerisinde kötülük barındırmayan meşru süreçleri tanımlarken, kaybedecek çok az şeyi olan insanların uyguladığı tehdit ve benzeri davranışlar yasal olmayan politik davranışlar olarak belirtilmektedir. Bunların haricinde kişinin yağcılık veya dalkavukluk yaparak karşı tarafın sevgisini kazanma çabası, güç sahibinin sürekli gözü önünde bulunarak iş yapıyor gibi görünmesi, baskı ve tehdit de informal güç arayışı olarak nitelendirilebilir.

Tablo 2.'de Farrell ve Petersen (1982: 407) tarafında geliştirilen politik davranış tipolojisi görülmektedir.

Tablo 2. Örgütlerde Politik Davranışların Tipolojisi

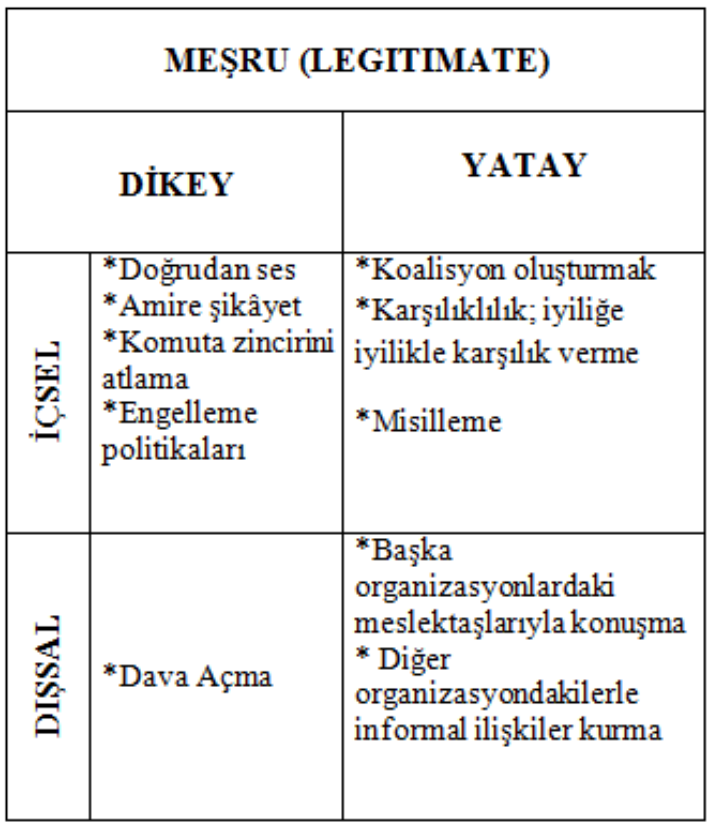

\section{YASAL OLMAYAN (ILLEGITIMATE)}

\begin{tabular}{|c|c|c|}
\hline \multicolumn{2}{|r|}{ DİKEY } & YATAY \\
\hline$\stackrel{\underline{w}}{\underline{2}}$ & $\begin{array}{l}\text { *Sabotaj } \\
\text { *Sembolik protestolar } \\
\text { * İsyanlar } \\
\text { *Ayaklanmalar }\end{array}$ & *Tehdit \\
\hline 必 & *Bilgi uçurma & $\begin{array}{l}\text { *Örgütsel ikilik } \\
\text { *Başka bir } \\
\text { organizasyona gidince } \\
\text { ilk organizasyona } \\
\text { sadakatsizlik }\end{array}$ \\
\hline
\end{tabular}

Kaynak: (Farrell ve Petersen, 1982: 407).

Tablo 2. incelendiğinde, politik davranışların (informal güç arayışı) çeşitli kaynaklardan beslenerek sergilenebileceği çıkarımı yapılabilecektir. Çünkü gerçekleştirilen her davranışın sırtını yasladığı bir kaynağı olması zorunluluktur. İnformal güç arayışı da çeşitli informal güç kaynaklarına dayanarak gerçekleştirilmektedir.

\section{4. İnformal Güç Kaynakları}

Literatür incelendiğinde güç kaynaklarını formal-informal çerçevesinde ele alan çok sınırlı sayıda çalışma (Barkema and Pennings 1998; Labun, 2012; Greve and Mitsuhashi, 2007; Peiró and Meliá, 2003) olduğu görülmektedir. Örgüt içerisindeki informal güç ilişkilerine dayanak oluşturan informal güç kaynaklarının göz ardı 
edilmesi litaratürde bir boşluk oluşturmuştur. Örgüt içi ilişkilerde formal güçten daha etkili olduğu düşünülen informal gücün araştırılarak bu boşluğun giderilmeye çalışılması literatüre katkı sağlayacaktır.

Literatür incelendiğinde Labun'un (2012: 12-14) informal güç öncüllerini (kaynaklarını) organizasyondaki pozisyon, yakın kişisel bağlar, güven verme, itibar olarak ifade ettiği görülmektedir. Barkema ve Pennings (1998: 985) ise bilgi ve malumatın önemli informal güç kaynaklarından olduğunu ve yöneticinin bu güç kaynaklarını kontrol edebilmesi gerektiğini ifade etmektedir. Greve ve Mitsuhashi’ye (2007: 1201) göre ise sosyal sermaye yöneticinin informal güç kaynağını oluşturmaktadır. Meliá ve Peiró (1984) French ve Raven'in beşli taksonomisini temel alarak yaptığı sınıflamada ödül gücü, yasal güç ve zorlayıcı gücü formal güç; uzmanlık ve benzeşim gücünü ise informal güç olarak ele almıştır (Akt. Peiró and Meliá, 2003: 17). Thompson (2014: 141) yükseköğretim kurumlarında yapmış olduğu çalışmanın sonucunda informal güç kaynaklarının zorlayıcı güç, uzmanlık gücü, beceri gücü, malumat gücü, üretim gücü, özdeşim gücü ve kaynak gücü temalarından oluştuğu sonucuna varmıştır. Katılımcılar tarafından tanımlanan en önemli informal güç kaynakları üretkenlik, malumat ve kaynak gücüdür. Milligan (2012) literatürdeki, özellikle French ve Raven'in sınıflamasını dikkate alarak informal güç kaynaklarının uzmanlık gücü, ödül gücü, kişisel güç ve malumat gücü olduğunu ifade etmiştir. Literatürde rastlanmasa da; mensubiyet (aynı değerleri paylaşma), favorizm, netvörk (sosyal ağ), kronizm, ahlaki tutum ve davranışlar informal gücün kaynakları arasında sayılabilir. Burada güç kaynakları kısaca açıklanacaktır.

\subsubsection{Organizasyondaki Pozisyon}

Kişinin hiyerarşik pozisyonundan bağımsız; kaynaklara yakınlık, bilgi akışındaki merkezilik gibi faktörlere bağlı olarak bulunduğu pozisyonu informal güç kaynağını oluşturur. Örneğin güç kaynağına (yönetici, uzman vb.) yakın bir odada ya da yöneticinin gidiş geliş güzergâhında olan bir alt düzey çalışanın herhangi bir sorun ya da isteğini yöneticisine iletme ihtimali daha fazladır. Yine bir organizasyondaki bilgi akışının merkezinde olmak informal güç kaynağını oluşturacaktır. A kişisi ile C kişisi arasındaki iletişimi sağlayabilmek için mutlaka uğranması gereken B kişisi olmak, A ve C kişisi üzerinde informal güce sahip olmak anlamına gelmektedir. Fakat burada dikkat edilmesi gereken nokta B kişisine uğranmak zorunda olunması hiyerarşideki pozisyonundan dolayı olmamalıdır. Aksi halde güç formal güce dönüşecektir. Labun (2012: 8) merkezilik ve yakınlık durumunu klasikleşmiş sekreter örneğiyle ifade etmektedir. Yönetici ile görüşmek istediğinizde, eğer sekreteri ile aranızın bozuk olduğu düşünülürse, sekreter görüşme talebinizi randevu sıralamasında en altlara koyacak hatta bazen araya bile kaynatabilecektir. Tersi bir durumda (sekreterle ilişkileriniz güçlü ise) hemen görüștürülme imkânı bile bulunabilecektir. Örnekte de görüldüğü gibi hiyerarşik pozisyon açısından bakıldığında önemli bir güç kaynağını elinde bulundurmayan yönetici sekreteri formal güce (yöneticiye) yakınlığı ve güç kaynağıyla iletişimdeki merkeziliği sebebiyle ciddi bir informal güce sahiptir.

\subsubsection{Yakın Kișisel Bağlar}

Yöneticilerin etkili olabilmesi için formal ve informal durumlarda işin iç yüzünü bilmeleri bir zorunluluktur (Kanter, 1979). Zaten insan sosyal bir varlık olması hasebiyle sürekli bilmek ister. Çünkü bilinmezlik tehlike, tehdit, vesvese demektir. Bilme ihtiyacıyla birlikte çevredekileri daha iyi tanıyabilmek için onlarla yakın ilişki kurulur. İşte bu kurulan yakın ilişkiler sonucu kişiler birbirlerinin isteklerini yerine getirmeyi kendileri için borç sayarlar. Bireyin güven, sadakat, dostluk gibi nedenlerle yakın bağlar kurduğu kişilerle arasındaki ilişkiler yakın bağ kurmayanlara göre daha fazladır. Bu ilişkiler sayesinde insanlar birbirini daha fazla tanıyarak birbirlerine olan güvenleri daha da artmaktadır. Artan güvenin etkisiyle kurulan yakın ilişkiler farklı açılardan informal güç kaynağı teşkil edebilecektir. Örneğin, yakın ilişkilere güvenerek insanlar birbirleri hakkında önemli ve kritik bilgilere sahip olabilecektir. Bilginin informal güç olduğu düşünüldüğünde bilgiye sahip olanların olmayanlara göre daha fazla informal güce sahip olduğu düşünülebilir. Bunun yanında bilgiler şantaj konusu yapılarak bilginin kaynağı olan kişi üzerinde informal güce sahip olunabilir. Diğer açıdan bakıldığında yakın ilişkide bulunan kişiler diğerinin isteklerini kırmayacak derecede duygusal bă̆ ile birbirlerine bağlıdır. Bu sayede de informal güç elde edilebilecektir.

\subsubsection{Güven}

Örgütsel açıdan bakıldığında güvenin faaliyetleri kolaylaştırıcı bir unsur olduğu görülecektir. Yöneticinin çalışanlarına, çalışanların yöneticisine, eşit statüdekilerin birbirlerine olan güveni şeklinde ele alınabilecek güven kavramı örgütlerdeki güç ilişkileri açısından önem arz etmektedir (Ergeneli vd., 2007: 43 ). İnformal güç de özünde güveni ima eder. Yani kişinin etrafına verdiği güven duygusu onlar üzerinde informal güç elde etmesini sağlar (Peiró and Meliá, 2003: 19). Bir astın yöneticisinde oluşturduğu güven duygusu üstüne bazı isteklerini yaptırabilme potansiyelini veya yöneticisinin astında oluşturduğu güven astın işinde daha özverili çalışmasını, 
örgüte katkısının artmasını beraberinde getirebileceği gibi, hiyerarşiye bağlı yaptırımdan bağımsız, üste; astlara karşı işlerin kolayca gördürülmesi potansiyelini verecektir. Bu bağlamda güven olgusu informal güç kaynağı olarak karşımıza çıkmaktadır.

\subsection{4. İtibar}

Hayattaki küçük şeyler bazen büyük sonuçlar ortaya çıkarabilmektedir. İtibar da başarı ile başarısılık arasındaki farkın çizilmesinde önemli bir etken olması hasebiyle sonuçları etkilemektedir. O yüzden itibar güçtür (Komisarjevsky, 2012). Çünkü örgüt içerisinde kişisel itibar zaman içerisinde işlerin düzgün şekilde yerine getirilmesi ve başkalarına yardım edilmesi ile kazanılabilecek bir durumdur (Zinko et al., 2012: 157 ). Yani itibar kişinin başkalarının zihninde kendisi ile ilgili oluşturduğu algısal bir kimliktir ve bu algısal kimlik gelecekle ilgili belirsizlikleri azaltır (Zinko et al., 2007: 165). Kişinin kendi kişisel çabaları sonucunda oluşturduğu bir alg1 olması nedeniyle bireye sağladığı güç informal güç olarak değerlendirilebilecektir. Çünkü formal-informal güç ayrımında kriter olarak organizasyondaki pozisyondan kaynaklanıp kaynaklanmadığı dikkate alınmaktaydı. Bu bağlamda itibar da bir informal güç kaynağı olarak ele alınabilecektir.

Diğer taraftan bakıldığında güven itibarın en önemli kaynağını oluşturmaktadır. Karatepe’ye (2008: 84) göre "itibar güvenilir olmaktır." Güven ise kişilere güç kazandırır. Dolayısıyla güven itibara kaynaklık ederken itibar da informal gücün en önemli kaynaklarından birini oluşturmaktadır. İtibardan beslenen informal gücün devamlılığının sağlanabilmesi için itibarın kaybedilmemesi, bu bağlamda güven duygusunun sürekli olarak muhafaza edilmesi gerekmektedir.

\subsubsection{Aynı Değerleri Paylaşma}

Aynı değerleri paylaşma; ideolojik görüş, hemşeri olma, etnosentrik tavır, cinsiyet, ırk ve benzeri açılardan aynı görüşe sahip olmayı ifade etmektedir. Yani Ferdinand Tönnies'in ifadesiyle cemaat oluşturmaktır. İlk defa cemaat (Gemeinschaft) kavramını ortaya koyan Ferdinand Tönnies cemaati; insan isteklerinin tam bir birlik hali olarak ifade etmektedir. Bu birlik/aynılık insanlar farklı yerlere dağılsa da devam eder. Fakat aynı değerleri paylaşma (mensubiyet) kişiler arasındaki ilişkilere bağlı olarak çeşitli formlar almaktadır (Tönnies, 2001: 22). Aynı şehirden olma (hemşeri), aynı ideolojik görüşten olma, dini anlamda aynı cemaatten olma ya da aynı ırk ya da cinsiyetten olma şeklinde sayabileceğimiz ve genel olarak - gıl, -gil, -c1, -ci, -cü gibi eklerle ifade edilen mensubiyet informal güç kaynakları arasında sayılabilecektir. Çünkü liyakat çerçevesinde olması gereken örgüt içerisinde bir pozisyona getirilme genellikle mensubiyet süzgecinden geçirilerek yapılmaktadır.

Mensubiyetin iki şekilde informal gücün kaynağını oluşturduğu düşünülebilir. Birincisi; aynı görüşe (ideoloji, cemaat, cinsiyet vb.) sahip olan bireyler arasındaki hiyerarşi çeşitli ortamlarda kalkacak hatta hiyerarşi tersine bile dönebilecektir. Örgüt içerisinde formal hiyerarşide yüksek pozisyonlarda olan ve bu sayede diğer kişi üzerinde formal gücü fazla olan bir kişi mensubiyet ilişkilerinin hâkim olduğu ortamlarda formal gücü kalmayarak diğer kişinin informal gücünün etkisi altında kalabilmektedir. Bu durum bir süre sonra öyle bir hal almaktadır ki; kurumsal kararlar kurum içerisindeki yöneticiler tarafından alınıyormuş gibi gösterildiği halde esasında perde arkası kahramanı olan informal güçler tarafından alınmaktadır.

İkincisi ve daha masumane olanı; aynı görüşü paylaşan bireyler informal ortamlarda da birbirleriyle bir araya gelerek yakın ilişkiler kuracaklar, bu sayede de güven ortamı tesis edebileceklerdir. Güven ve yakın ilişkiler ise informal gücün önemli kaynaklarındandır. Çünkü kendisine güvenilen kişi hiyerarşik pozisyonda alt seviyelerde olsa bile amirlerini etkileyebilme potansiyeline sahiptir.

\subsubsection{Akrabalık, Dostluk ve Siyasi Tanıdıklık}

Akrabalık, dostluk ya da siyaset erkânından tanıdık kişilerin olması da informal güç kaynaklarından sayılabilecektir. Çünkü akraba olan kişiler birbirine destek çıkacak akrabalık bağları diğer kişinin davranışlarını etkileme potansiyelini de beraberinde getirecektir. Yine dostlar arasında hiyerarşi yok olacak, informal ilişkiler devreye girecektir. Siyasi tanıdıklık açısından bakıldı̆̆ındaysa, siyaset erbabından tanıdığı olanların diğerleri üzerinde bir güce sahip olduğu görülecektir. Günlük hayatta ya da medyada karşılaşılan "sen benim kim olduğumu biliyor musun?" veya "X bakanının yeğeni isen her işin hallolur" gibi cümleler de siyasi tanıdıklığın nasıl informal güç kaynağı olabileceği konusuna 1şık tutmaktadır.

Literatür incelendiğinde bir kimsenin beceri, kabiliyet, eğitim seviyesi gibi özellikleri yerine sadece akrabalık derecelerine bakılarak istihdam edilmesi ya da terfi ettirilmesi durumunun nepotizm (akraba kayırmacılığı) (Özler vd., 2007: 438) olarak ifade edildiği görülecektir. Yani kişinin resmi pozisyonundan kaynaklanmadığı halde sırf 
akrabalık ilişkilerinden doğan bir informal gücü vardır. Özler ve Büyükarslan’a (2011: 276) göre ahbap, dost ve arkadaş gibi tanıdıklara tolerans gösterilerek kayırılması favorizm yani eş-dost kayırmacılığı olarak tanımlanmaktadır. Bakıldığında sırf dost, arkadaş vb. olması hasebiyle alınan kararları etkileyebilme potansiyelinin varlığı görülecektir. Yani sadece akraba, eş dost olmak bir informal güç kaynağı olmaktadır.

\subsubsection{Sosyal İlişkiler (Sosyal Ăg/Netvörk)}

Sosyal ilişkilerde merkez konumda olmanın güç elde etme üzerinde önemli derecede etkisi vardır. Freeman (1979) merkeziliğin ölçümlenebilmesi için a) bağlantıların sayısı b) arasındalık ve c) yakınlığa bakılması gerektiğini vurgulamaktadır. Bağlantı sayısı kişinin doğrudan bağlantılı olduğu diğer kişilerin sayısını ifade eder. Arada olmak ise iki şey arasındaki bağı kurmayı ifade eder ve eğer Ali ile Veli yalnızca Berk vasıtasıyla iletişim sağlayabiliyorsa Berk aradadır, aynı zamanda Ali ile Veli üzerinde güce sahiptir. Yakınlık ise bir kişinin başka bir kişiye fiziki olarak mesafesini ifade eder. Merkezde olan her zaman çevrede olanlara eşit uzaklıktadır fakat çevrede olanların birbirine uzaklığı daha fazladır.

Örgütsel anlamda düşünüldüğünde netvörk; iş akış ağ1, iletişim ağ1 ve arkadaşlık ağ1 olmak üzere üç çeşit ağdan oluşmaktadır (Brass, 1984: 519). Ağ perspektifinden güce bakıldığında informal sosyal ilişkiler kişiye güç kazandırır (Liu and Moskvina, 2016: 2). Örgütsel yapıdan kaynaklanmadığından dolayı bu kazanılan güç de informal güç olarak adlandırılabilir. Mitzberg (1983: 127) de yöneticinin kurduğu iletişim ağı sayesinde elde ettiği bilgilerin informal güç kaynaklarını oluşturacağını belirtmektedir.

Brass ve Burkhart (1993: 462) yapmış oldukları çalışmanın sonucunda güce temel teşkil eden iki tür yapısal pozisyon olduğuna ulaşmışlardır: formal pozisyon yani hiyerarşik seviye, informal pozisyon yani netvörk. Güç, sosyal sistemdeki pozisyondan kaynaklanır diyen Brass da bu iki yapısal güç kaynağını formal (hiyerarşik kademe) ve informal (netvörk konumu) olarak belirtmektedir (Brass, 2002: 141). Kanter (1981: 222) ağ (netvörk) ve akran ilişkilerinin önemli güç kaynaklarından olduğunu ifade etmektedir.

Sanal gerçeklikler olarak ifade edilebilen sosyal medya (Feysbuk, Tivitır, Linkedin vb.) hem gerçek dünyada hem de sanal ortamda birbirimiz üzerinde önemli ölçüde etkiye sahiptir (Chaturvedi et al., 2011: 674). Potansiyel etki olarak ifade edilen güç açısından bakıldığında da aslında bilgisayar ve internet temelli ağ bağlantılarından sosyal medyanın önemli bir informal güç aracı olduğu görülecektir. Eskiden üst pozisyonlarda bulunan birine ulaşabilmek belki ayları alırken günümüzde bu süre, sosyal medyadan yapılan bir gündemleme (heşteg) sayesinde, saniyelere bile düşebilmektedir. Bu noktada Arap Baharı ya da 15 Temmuz olaylarında insanların ne kadar hızlı meydanlara toplandığ 1 örnek olarak gösterilebilir.

Yine kişinin sempatik davranışları, uzmanlığı, bilgisi, babacan tavrı gibi çeşitli kişisel özellikleri sayesinde oluşturduğu geniş iletişim ağının bir sonucu olarak oluşturduğu referanslar da informal güç kaynaklarından sayılabilir. Çünkü referanslar diğer tarafın kararlarını etkileyebilme potansiyeline sahip etmenlerdir. Bu yönüyle bakıldığında referanslar da informal güç kaynaklarındandır.

\subsection{Formal-İnformal Güç İlişkisi}

Ortaya çıkan bir durumun formal mi yoksa informal mi olduğunu belirleyecek olan daha çok bağlamdır. Aynı eylem bazı durumlarda formal olabilirken başka bir bağlama geçildiğinde informal olabilecektir. Erdem ve diğerleri (2007: 8) formalite ve informalitenin kesiştiği gri alanların olduğunu ifade ederek bunu piknik örneği ile izah etmişlerdir. Bir yöneticinin herhangi bir örgütsel problemi, piknik ortamında tartışmaya açması gri alana örnek gösterilebilir. Piknik ortamında kişi örgüt sınırları içerisinde olmasa da yöneticilik vasfı devam etmektedir ve alınan kararlar resmiyet kazanacaktır. Bu kısım işin formal boyutunu oluşturmaktadır. Mekân açısından bakıldığında ise piknik informal bir ortamdır ve yönetici çalışan ilişkilerinin informal ortamlarda daha esnek olması nedeniyle çalışanlar görüş ve önerilerini daha rahat ifade edebileceklerdir. Bu kısım da işin informal boyutunu oluşturacaktır.

Gücün kaynağı ve kullanımı; kaynak, hedef ve bağlam arasındaki ilişkilere ve bunların bireysel özelliklerine bağlıdır (Cobb, 1984: 485). Özellikle de informal güçte bağlam çok önemlidir. Çünkü bir durumda üst olan bir kişi başka bir durumda ast konumunda bulunabilmektedir. Örneğin başhekim ya da bir tıp fakültesi dekanı hastanedeki diğer hekimlere göre üst konumundayken informal ortamlarda oluşturduğu bir ilişkide ast konumuna gelebilmektedir. Bu durumun konuyla ilgili en önemli sonucu ise informal ortamdaki gücün formal ortamlarda amirin kararlarını etkilemesidir. Walls ve Berrone'e (2015: 304) göre formal güç ile informal güç birbirlerini tamamlayıcı niteliktedirler. Buradan hareketle eğer bir organizasyonda örgütü oluşturan bireylerin gücü iyi algılanır ve doğru yönlendirilirse örgütü amaçlarına ulaştıracağı, fakat kişilerin formal güçleri ön plana çıkartılarak 
informal güçleri göz ardı edilirse örgütün yıkımına kadar gidebilecek negatif sonuçlara sebep olabileceği çıkarımı yapılabilecektir. Olson'a (2004: 95) göre informal gücünü artıranlar daha fazla formal güç elde edeceklerdir. Örneğin informal güç kaynaklarından netvörkü geniş olan yöneticiler zayıf olanlara göre formal güçlerini artırmak için daha fazla firsata sahiptir.

French ve Raven (1959) tarafından yapılan beşli sınıflama formal ve informal açıdan değerlendirildiğinde Meliá ve Peiró'ye (1984) göre; ödül gücü, yasal ve zorlayıcı güç formal güç; uzmanlık ve benzeşim gücü ise informal güç olarak ele alınabilir. Çünkü formal gücün temeli hiyerarşik pozisyondaki yapısal güç kaynaklarına dayanırken, informal gücün temeli formal yapılardan bağımsız kişisel güç kaynaklarına dayanır (Akt. Peiró and Meliá, 2003: 17). Meliá ve Peiró'nun bu sınıflama ile formal gücü "rol özelliği”; informal gücü ise bireyin kişisel arka planı, deneyimleri ve yetkinlikleri ile ilgili bir "kişisel özellik" olarak ele aldığı görülmektedir (Norbom and Lopez, 2016: 21).

Formal örgütlenmelerde gücün temelini yasal otorite oluştururken informal örgütlenmelerde uzmanlık ve özdeşim gücü sayesinde oluşturulan kişiler arası ilişkiler ve başkalarının ihtiyaçlarını karşılayabilme oluşturur (Farris, 1979: 40). Kişinin formal gücü organizasyonun hiyerarşik yapısındaki pozisyonuna dayanır. Bu yüzden çeşitli araştırmacılar tarafından dikey, yapısal veya hiyerarşik güç olarak ifade edilmiştir (Thompson, 2014: 15). Formal güç kişinin otoritesine dayanır ve örgütteki hiyerarşik pozisyonundan kaynaklanır. Fakat güç, her zaman olduğu gibi, kişinin örgüt içerisindeki formal rollerinden gelmeyerek bazen kişiliğinden, yeteneklerinden, kapasitesinden ya da kişiler arası ilişkilerinden gelebilmektedir (George and Jones, 2011: 374-376). İşte bu hiyerarşik pozisyona dayanmayan güç informal güç olarak ifade edilmektedir.

Formal güç kişinin örgütteki tanımlanmış pozisyonu sonucunda elde ettiği güç iken informal güç bireyin kişisel özellikleri, ilişkileri sayesinde elde ettiği güçtür (Blau, 1964'ten Akt. Greve and Mitsuhashi, 2007: 1199; Meydan, 2010: 40; Rayner et al., 2002: 12). Pozisyon gücü formal gücü oluştururken, kişisel güç ise informal gücü oluşturmaktadır (Paynton, 2008: 2). Yani bir organizasyondaki iş görevlerinin, yetki ve sorumlulukların nasıl dağıtılacağını, sınıflanacağını ve koordine edileceğini (Robbins and Judge, 2011: 480) ifade eden örgütsel yap1 kaynaklı güçler formal gücü ifade ederken informal güç bu pozisyondan bağımsız olarak başkalarını etkileyebilme kapasitesini ifade etmektedir.

Formal güç, gücü meşrulaştıran hiyerarşik yapılarıyla bağlantılı otoritedir. İnformal güç ise büyük ölçüde hiyerarşik yapıların dişında uygulanan etkidir (Thompson, 2014: 12). Yani formal güç kişinin pozisyonundan kaynaklı olarak organizasyonun ona verdiği haklar, informal güç ise kişinin kendi çabasıyla elde ettiği başkalarını yönlendirme yeteneği şeklinde ifade edilebilir. İnformal gücün kaynağı yasal olabildiği gibi illegal de olabilir. Fakat formal gücün kaynağı yasaldır.

Formal güç akışı yukardan aşağıya olmasına karşın informal güç akışı her taraftan olabilir. Ancak kişinin organizasyondaki pozisyonu kişisel ilişkileri etkileyeceğinden, dolaylı olarak informal gücü de etkiler. Aynı hiyerarşik pozisyonda olanların, üst pozisyondakilere göre, birbirini daha çok informal güç kaynaklarına dayalı etkiledikleri görülmektedir. Formal güç asimetrik yapıdayken informal güç karşılıklıdır (Peiró and Meliá, 2003: 18-20). İnformal güç herhangi bir pozisyondaki kişi tarafından yine herhangi bir pozisyondaki kişiye karş1 kullanılabilirken formal güç sadece yukardan aşağıya doğru astlara karşı kullanılabilir. Formal güce sahip bireyler aynı zamanda informal güce de sahip olabilirler (McGrath, 2010: 3). Fakat unutulmamalıdır ki, formal gücü olmayan bir kişi de informal güce sahip olabilir.

Özetle, doğadaki tüm canlılar yaşamlarını sürdürebilmek için sürekli olarak etrafına egemen olma dürtüsüyle hareket etmektedirler. İnsanlar da bu dürtüden nasibini alarak etrafına egemen olma, başkalarının davranışlarını manipüle edebilme motivasyonuyla hareket etmektedir. Bunu başarabilmek için de sürekli bir güç arayış1, güç elde etme telaşı içerisindedir. Genel anlamda bakıldığında literatürde güç, potansiyel etki olarak tanımlanmaktadır. Formal-informal güç ayrımına gidildiğinde formal güç kişinin organizasyondaki pozisyonundan kaynaklı etkileme kapasitesi olarak tanımlanabilir. Yani formal güç diye ele alınan olgu yetkiyi çağrıştırmaktadır. İnformal güç ise kişinin organizasyondaki pozisyonundan bağımsız olarak, çeşitli kaynaklardan beslenen başkalarını etkileyebilme kapasitesi olarak tanımlanabilir. İnformal gücün kaynağını bireyin kendisi (başarısı, zekâsı, sempatikliği, tecrübesi, netvörkü vb.) oluşturmaktadır. Literatürde kısmen ele alınmış olsa da informal güç konusunun bir portresinin çizilebilmesi için derinlemesine çalışmalar yapılması gerekmektedir. Yukarıda informal güç kaynağı olduğunu varsaydığımız durumların gerçekten informal güç kaynağı olup olmadığının ya da bunlara ek informal güç kaynaklarının olup olmadığının tespiti sahada yapılacak uygulamaya bağlıdır. Bu sebeple çalışmanın ikinci kısmında informal güç ile ilgili uygulamaya yer verilecektir. 


\section{SONUÇ VE DEĞERLENDİRME}

Güç hayatın her alanında kendisine yer bulabilmiş bir olgudur. Ekonomiden askeriyeye, siyasetten sağlığa her alanda karşılaşılması mümkün olan bir kavram olması sebebiyle hayatın içerisine nüfuz etmiş durumdadır. Belki de bu sebepten dolayıdır ki literatürde güçle ilgili yapılmış çok fazla tanım mevcuttur. Bunlardan kavramı en çok karşılayan ise "güç potansiyel etkidir" tanımıdır. Herhangi bir olgunun açıklanabilmesi başka bir olguya bağlıdır. Yani başka kavramlar sayesinde açıklanabilir. Güç kavramı da çeşitli kavramlarla ilişki içerisinde kendisine anlam kazandırabilmektedir. Güç kavramı da litertürde otorite, yetki, etki, uyma, itaat, bağımlılık, iktidar gibi kavramlarla ilişkilendirilmektedir. Fakat literatürde bu ilişkilendirmenin bazen kavramların bir birinin yerlerine kullanılması şeklinde olduğu, bu durumun da güç kavramında anlam kargaşasına sebep olduğu görülmüştür.

Gücün kaynakları literatürde çeşitli şekillerde sınıflandırılmıştır. En kabul gören sınıflandırma ise French ve Raven tarafından yapılan beşli taksonomidir. Bu sınıflamaya göre güç kaynakları ödül gücü, zorlayıcı güç, uzmanlık gücü, özdeşim gücü ve yasal güç şeklindedir. Her ne kadar literatürde çeşitli sınıflamalar olsa da güç kavramına temelden bir yaklaşımla, formal-informal perspektifinden bakılarak yapılan bir sınıflamaya rastlanmamıştır. Güç kaynakları açısından bakıldığında ise çok sınırlı sayıda çalışmanın olduğu görülmektedir. Yapılan bu sınırlı sayıdaki çalışmalarda informal güç kaynakları; organizasyondaki konum, yakın kişisel bağlar, güven verme, itibar, aynı değerleri paylaşma, akrabalık-dostluk-siyasi tanıdıklık, sosyal ilişkiler şeklinde belirtilmiştir.

Formal güç ile informal güç ilişkisel anlamda değerlendirildiğinde ise bağlamın çok önemli olduğu görülecektir. Örneğin bir hastanede başhekim diğer hekimler üzerinde formal güce sahipken herhangi bir hekim informal gruplarda başhekimden daha yüksek bir konuma (sendika temsilcisi, siyasi güçlere yakınlık, herhangi bir yere mensubiyeti olup orada başhekimden daha üst konumda olma vb.) sahipse hekim üzerinde informal güce sahip olacaktır. Ya da görev yaptığı hastanede başhekim olan bir kişi formal güce sahipken, başka bir hastaneye gittiğinde ya da günlük işlerini yürütürken hastanede başhekim olduğunu söylemesi sonucu bir ayrıcalık elde ediyorsa başhekimlik onun için informal güce dönüşmüş olacaktır.

İnformal gücün nasıl algılandığı da önemli bir konudur. İnformal güç iki boyutta ele alınabilir. Birincisi illegalite boyutu diğer ise legal olduğu halde formal prosedürlerde yazmayan işleyiş esnasında ortaya çıkan boyutudur. Bu iki boyutla gerek günlük hayatta gerekse iş hayatında sürekli karşılaşılmaktadır. Var olan bir şey yok sayılmak yerine varlığı kabul edilerek kurum yararına kullanılmalı, olumsuz sonuçlarından kaçınılmalıdır. İnformal güçlerden maksimum düzeyde istifade edilebilmesi için;

1. Yöneticiler kurum içerisindeki informal güç sahibi kişilerle iletişim haline geçerek bu gücü kurumun yararına olacak şekilde kanalize etmeli,

2. Yöneticiler informal güç kaynaklarından olan iletişim becerilerini ortaya koyarak çalışanlarla mümkün olduğunca birebir ilişki kurmalı ve bu sayede onlara değerli olduğunu hissettirmelidir,

3. Kurumdaki informal güçler göz ardı edilmemeli, kararlar alınırken ya da kurumda bir görev değişikliği yapılırken informal güçler de göz önüne alınmalıdır.

4. İnformal gücün tüm yönleriyle portresinin çizilebilmesi için nitel yöntemle yapılacak bir çalışmaya ihtiyaç vardır. Araştırmacıların bu çalışmayı biraz daha ileriye taşıyarak nitel yöntemle hazırlanmış keşifsel bir informal güç çalışması tasarlamaları literatüre katkı sağlayacaktır.

\section{KAYNAKÇA}

Aldrich, H. E. and Pfeffer, J. (1976).“Environment of Organizations”, Annual Review of Sociology, 2, 79-105.

Altay, H. (2004). "Güç Mesafesi, Erkeklik-Dişilik ve Belirsizlikten Kaçınma Özellikleri ile Başarı Arasındaki İlişkilerin İncelenmesine Yönelik Bir Araştırma”, Süleyman Demirel Üniversitesi İktisadi ve İdari Bilimler Fakültesi Dergisi, 9(1), 301-321.

Altınkurt, Y., Yılmaz, K., Erol, E. ve Salalı, E. T. (2014). “Okul Müdürlerinin Kullandığı Güç Kaynakları ile Öğretmenlerin Örgütsel Sinizm Algıları Arasındaki İlişki”, Journal of Teacher Education and Educators, $3(1), 225-252$.

Asch, S. E. (1961). "Effects of Group Pressure Upon the Modification and Distortion of Judgments", M. Henle (Ed.), Documents of Gestalt Psychology, In (222-236), Los Angeles: University of California Press. 
Barkema, H. G. and Pennings, J. M. (1998). "Top Management Pay: Impact of Overt and Covert Power", Organization Studies, 19(6), 975-1003.

Başaran, S. ve Duygulu S. (2014). "Hemşirelikte Güç Kavramının Analizi”, Hacettepe Üniversitesi, Hemşirelik Fakültesi Dergisi, 1(3), 62-73.

Bateman, T. S. and Zeithaml, C. P. (1990). Management: Function and Strategy, Boston: Homewood.

Bayrak, S. (2000). "Yönetimde Bir İhmal Konusu Olarak Güç ve Güç Yönetimi I”, Süleyman Demirel Üniversitesi İktisadi ve İdari Bilimler Fakültesi Dergisi, 5(2), 21-34.

Bayraktaroğlu, S. (2000). “Klasik Örgütsel Güç Kuramlarından Clegg’in ‘Güç Devreleri’ Yaklaşımı”, Bilgi, 3(2), 109-122.

Blau, P. M. (1986). Exchange \& Power in Social Life, London: Transaction Publishers.

Bolman, L. G. and Deal, T. E. (2003). Reframing Organization, San Francisco: Jossey-Bass.

Brass, D. J. and Burkhardt, M. E. (1993). "Potential Power and Power Use: An Investigation of Structure and Behavior", The Academy of Management Journal, 36(3), 441-470.

Brass, D. J. (1984). "Being in the Right Place: A Structural Analysis of Individual Influence in an Organization", Administrative Science Quarterly, 29(4), 518-539.

Brass, D. J. (2002). “Intraorganizational Power and Dependence”, J. A. Baum (Ed.) Companion to Organizations, In (138-157), Oxford: Blackwell.

Can, H., Aşan, Ö. ve Aydın, E. M. (2006). Örgütsel Davranış, İstanbul: Arıkan Yayınevi.

Can, N. ve Çelikten, M. (2000). “Alt Düzey Personelin Güç Kaynağı, Erciyes Üniversitesi Örneği”, Kuram ve Uygulamada Eğitim Yönetimi, 22, 269-290.

Canetti, E. (1978). Crowds and Power, C. Stewart (Çev), New York: Continuum Publishing.

Cartwright, D. and Zander, A. (1968). "Power and Influence in Groups: Introduction", D. Cartwright and A. Zander (Ed.), Group Dynamics Research and Theory, In (215-235), New York: Harper\&Row.

Cartwright, D. (1959). "Power: A Neglected Variable in Social Psychology”, D. Cartwright (Ed.), Studies in Social Power, Ann Arbor, In (1-14), Michigan: University of Michigan.

Carzo, R. and Yanouzas, J. N. (1967). Formal Organization A Systems Approach, Illinois: Dorsey Press.

Chaturvedi, A. R., Dolk, D. R. and Drnevich, P. L. (2011). “Design Principles For Virtual Worlds”, MIS Quarterly, 35(3), 673-684.

Cobb, A. T. (1980). "Informal Influence in the Formal Organization: Perceived Sources of Power Among Work Unit Peers", The Academy of Management Journal, 23(1), 155-161.

Cobb, A. T. (1984). “An Episodic Model of Power: Toward an Integration of Theory and Research", The Academiy of Management Review, 19(3), 482-493.

Cürcânî, S. Ş. (1997). Arapça-Türkçe Terimler Sözlüğü, A. Erkan (Çev.), İstanbul: Bahar Yayınları.

Çalışkur, A. (2016). “Örgütlerde Güç Olgusu ve Gücün Kullanımı”, Çankırı Karatekin Üniversitesi Sosyal Bilimler Enstitüsü Dergisi, 7(1), 29-48.

Çavuş, M. F. ve Harbalıŏlu, M. (2016). "Yöneticinin Güç Kaynakları Algısı ve Örgütsel Vatandaşlık Davranışı: Konaklama İşletmeleri Üzerine Bir Araştırma”, Niğde Üniversitesi, İktisadi ve İdari Bilimler Fakültesi Dergisi, 9(1), 117-130.

Çörekçioğlu, H. (2014). “Nietzsche’de Güç İstemi Kavramı”, Felsefe ve Sosyal Bilimler Dergisi, 17(17), 35-46.

Daft, R. L. (1991). Management, Orlando: Dryden Press.

Daft, R. L. (2008). Organization Theory and Design, New York: Cengage Learning. 
Daft, R. L., Murphy, J. and Willmott, H. (2010). Organization Theory and Design, Hampshire: Cengage Learning EMEA.

Dahl, R. A. (1957). “The Concept of Power”, Behavioral Science, 2(3), 201-215.

Dahrendorf, R. (1959). Class and Class Conflict in Industrial Society, Stanford: Stanford University Press.

Devellioğlu, F. (1993). Osmanlıca-Türkçe Ansiklopedik Lügat, Ankara: Aydın Kitabevi Yayınları.

Durukan, H. (2003). "Yönetimde İnsan İlişkileri”, Kastamonu Eğitim Dergisi, 11(2), 277-284.

Emerson, R. M. (1962). “Power-Dependence Relations”, American Social Review, 27(1), 31-41.

Erdem, R., İzgüden, D. ve Erdem, İ. (2017). “İnformalitenin Kavramsal Çerçevesi ve Yönetim Düşüncesindeki Yeri”, R. Erdem (Ed.), Yönetimde İnformalite, içinde (5-43), İstanbul: Beta Yayınevi.

Eren, E. (2015). Örgütsel Davranış ve Yönetim Psikolojisi, İstanbul: Beta Yayınevi.

Ergeneli, A., Ar1, G. S. and Mertin, S. (2007). "Psychological Empowerment and its Relationship to Trust in Immediate Managers", Journal of Business Research, 60(1), 41-49.

Etzioni, A. (1975). A Comparative of Complex Organizations: On Power, Involvement, and Their Correlates, New York: The Free Press.

Fabianke, J. (1999). Power in Workforce Development Legislation: A Case Study of the $76^{\text {th }}$ Texas Legislative Session, PhD Thesis, Baylor University, Waco.

Farrell, D. and Petersen, J. C. (1982). "Patterns of Political Behavior in Organizations", The Academy of Management Review, 7(3), 403-412.

Farris, G. F. (1979). "The Informal Organization in Strategic Decision-Making”, International Studies of Management and Organization, 9(4), 37-62.

Fayol, H. (2008). Genel ve Endüstriyel Yönetim, M. A. Çalıkoğlu (Çev.), Ankara: Adres Yayınları.

Finkelstein, S. and D'Aveni, R. A. (1994). "CEO Duality as a Double-Edged Sword: How Boards of Directors Balance Entrenchment Avoidance and Unity of Command”, The Academy of Management, 37(5), 10791108.

Freeman, L. C. (1979). “Centrality in Social Networks: Conceptual Clarification”, Social Networks, 1(3), 215239.

French, J. R. P. and Raven, B. (1959). “The Bases of Social Power”, D. Cartwright (Ed.), Studies in Social Power, Ann Arbor, In (150-167), Michigan: University of Michigan.

George, J. M. and Jones, G. R. (2011). Understanding and Managing Organizational Behavior, New Jersey: Pearson.

Gibson, J. L., Ivancevich, J. M. and Donelly, J. H. (1991). Organizations, Boston: Homewood.

Giddens, A. and Sutton, P. W. (2014). Sosyolojide Temel Kavramlar, Ankara: Siyasal Kitabevi.

Giddens, A. (1993). New Rules of Sociological Method, Cambridge: Polity Press.

Giddens, A. (2005). Sosyoloji, Ankara: Ayraç Kitabevi.

Gold, M. (1968). "Power in The Classroom", D. Cartwright and A Zander (Ed.), Group Dynamics Research and Theory, In (251-258), New York: Harper\&Row.

Gove, P. B. (1981). Webster's Third New International Dictonary, Massachusetts: Merriam Company.

Greenberg, J., Baron, R. A., Sales, C. A. and Owen, F. A. (2000). Behaviour in Organizations, Ontario: Prentice Hall.

Greene, C. N. and Podsakoff, P. M. (1981). "Effects of Withdrawal of a Performance-Contingent Reward on Supervisory Influence and Power", The Academy of Management Journal, 24(3), 527-542. 
Greve, H. R. and Mitsuhashi, H. (2007). "Power and Glory: Concentrated Power in Top Management Teams", Organization Studies, 28(8), 1197-1221.

Griffin, R. W. and Moorhead, G. (2013). Organizational Behavior: Managing People and Organization, SouthWestern: Cengage Learning.

Gümüş, A. (2011). "Güç, İktidar, Sınıf ve Statü Üzerine Bazı Tartışmalar-Mühendis ve Öğretmen Örneği”, Sosyoloji Araştırmaları Dergisi, 14(1), 68-133.

Güney, S. (2008). Davranış Bilimleri, Ankara: Nobel Yayınevi.

Güney, S. (2011). Örgütsel Davranış, Ankara: Nobel Yayınevi.

Gürol, M. ve Turhan, M. (2005). "Yönetim Fonksiyonları Bağlamında Uzaktan Eğitim Yönetimi”, The Turkish Online Journal of Educational Technology, 4(2), 83-89.

Hançerlioğlu, O. (1996). Toplumbilim Sözlüğü, İstanbul: Remzi Kitabevi.

Hançerlioğlu, O. (2010). Felsefe Sözlüğü, İstanbul: Remzi Kitabevi.

Hickson, D. J., Hinings, C. R., Lee, C. A., Schneck, R. E. and Pennings, J. M. (1971). “A Strategic Contingencies' Theory of Intraorganizational Power”, Administrative Science Quarterly, 16(2), 216-229.

Hinings, C. R., Hickson D. J., Pennings, J. M. and Schneck, R. E. (1974). "Structural Conditions of Intraorganizational Power", Administrative Science Quarterly, 19(1), 22-44.

Hinkin, T. R. and Schriesheim, C. A. (1989). "Development and Application of New Scales to Measure the French and Raven (1959) Bases of Social Power”, Journal of Applied Psychology, 74(4), 561-567.

Hirschman, A. O. (1970). Exit, Voice and Loyalty: Responses to Decline in Firms, Organizations, and States, Cambridge: Harvard University Press.

Hofstede, G. (2001). Culture's Consequences, London: Sage Publications.

Hogg, M. A. and Vaughan, G. M. (2011). Sosyal Psikoloji, İ. Yıldız ve A. Gelmez (Çev.), Ankara: Ütopya Yayınevi.

Hortaçsu, N. (2012). En Güzel Psikoloji, Sosyal Psikoloji, Ankara: İmge Kitabevi.

http://www.nisanyansozluk.com/?k=güç, (Erișim Tarihi: 20. 10. 2017).

http://www.nisanyansozluk.com/?k=iktidar, (Erişim Tarihi: 20. 10. 2017).

http://www.tdk.gov.tr/index.php?option=com_gts\&arama=gts\&guid=TDK.GTS.59ea0a90b3e696.45720401, (Erişim Tarihi: 20. 10. 2017).

http://www.tdk.gov.tr/index.php?option=com_gts\&arama=gts\&guid=TDK.GTS.59ea0a977edb21.09921547, (Erisim Tarihi: 20.10.2017).

Isaac, J. C. (1987). “Beyond The Three Faces of Power: A Realist Critique”, Polity, 20(1), 4-31.

Jahoda, M. (1956). "Psychological Issues in Civil Liberties", American Psychologist, 11(5), 234-240.

Jones, G. (2010). Organizational Theory, Design and Change, New Jersey: Pearson Education.

Kanter, R. M. (1979). “Power Failure in Management Circuits”, Harvard Business Review, 57(4), 65-75.

Kanter, R. M. (1981). "Power, Leadership and Participatory Management”, Theory Into Practice, 20(4), $219-224$.

Kanter, R. M. (1993). Men and Women of the Corporation, New York: BasicBooks.

Karatepe, S. (2008). “İtibar Yönetimi: Halkla İlişkilerde Güven Yaratma”, Elektronik Sosyal Bilimler Dergisi, 7(23), 77-97.

Kelman, H. C. (1958)."Identification, and Internalization: Three Processes of Attitude Change”, The Journal of Conflict Resolution, 2(1), 51-60. 
Kemikkıran, N. (2015). “Güç Mesafesi Yüksekse Eşitsizlik mi İstenir?”, Siyasal Bilgiler Fakültesi (SBF) Dergisi, 70(2), 317-344.

Kırel, A. Ç. (1998). Örgütlerde Güç Kullanımı, Çalışanların Algıladıkları Güç ve Tepkileri Üzerine Bir Uygulama, Eskişehir: Anadolu Üniversitesi Yayınları.

Kızanlıklı, M. M., Koç, H. ve Kılıçlar, A. (2016). “Örgütsel Güç ve Gücün Kaynakları Üzerine Kavramsal Bir İnceleme", İşletme Araştırmaları Dergisi, 8(4), 488-504.

Kipnis, D., Schmdit, S. M. and Wilkinson, I. (1980). "Intraorganizational Influence Tactics: Explorations in Getting One's Way”, Journal of Applied Psychology, 65(4), 440-452.

Koçel, T. (2011). İşletme Yöneticiliği, İstanbul: Beta Yayınevi.

Kolarska, L. and Aldrich, H. (1980). "Exit, Voice and Silence: Consumers' and Managers' Responses to Organizational Decline”, Organization Studies, 1(1), 41-58.

Komisarjevsky, C. (2012). Power of Reputation: Strengthen The Asset That Will Make or Break Your Career, Reputation Retrieved from https://ebookcentral.proquest.com.

Kreitner, R. (2009). Management, Boston: Houghton Mifflin Harcourt Publishing Company.

Labun, A. (2012). Social Networks and Informal Power in Organizations, University of Groningen.

Liu, J. and Moskvina, A. (2016). "Hierarchies, Ties And Power in Organizational Networks: Model and Analysis", Social Network Analysis and Mining, 6(106), 1-26.

Lusch, R. F. (1976). "Sources of Power: Their Impact on Intrachannel Conflict”, Journal of Marketing Research, 13(4), 382-390.

Luthans, F. (2011). Organizational Behavior, New York: McGraw-Hill.

Marshall, G. (1999). Sosyoloji Sözlüğü, O. Akınhay ve D. Kömürcü (Çev.), Ankara: Bilim ve Sanat Yayınları.

McGrath, D. L. (2010). The Abuse of Formal and Informal Power: Workplace Bullying as a Dichotomous Construct. Paper presented at the 2nd Global Conference on Bullying and the Abuse of Power: From the Playground to International Relations, 8-10 November, Michna Palace, Prague, Czech Republic, 1-9.

Meydan, C. H. ve Polat, M. (2010). "Liderin Güç Kaynakları Üzerine Kültürel Bağlamda Bir Araştırma”, Ankara Üniversitesi SBF Dergisi, 65(4), 123-140.

Meydan, C. H. (2010). Örgüt Kültürü, Örgütsel Güç ve Örgütsel Adalet Algılarının Bireyin İş Tatmini ve Örgüte Bağlılığı Üzerine Etkisi: Kamuda Bir Araştırma, Doktora Tezi, Kara Harp Okulu Savunma Bilimleri Enstitüsü, Ankara.

Milligan, B. (2012). How to Use Formal and Informal Power on Your Dairy, https://www.progressivedairy.com/topics/management/how-to-use-formal-and-informal-power-onyour-dairy, (Erişim Tarihi: 03.04.2018).

Mintzberg, H. (1983). Power In and Around Organizations, Englewood: Prentice Hall.

Morgan, G. (2006). Images of Organization, California: Sage Publications.

Munduate, L. and Dorado, M. A. (1998). "Supervisor Power Bases, Co-Operative Behaviour and Organizational Commitment”, European Journal of Work and Organizational Psychology, 7(2), 163-177.

Newstrom, J. W. and Davis, K. (1997). Organizational Behavior, Boston: McGraw-Hill.

Norbom, H. M. and Lopez, P. D. (2016). "Leadership and Innovation: Informal Power and Its Relationship to Innovation Culture", Journal of Leadership Studies, 10(1), 18-31.

Norbom, H. M. (2009). Informal Power, Innovative Cutures, and Online Communication Use in Horizontal Organizations, PhD Thesis, Alliant International University, Los Angeles.

Northcraft, G. B. and Neale, M. A. (1990). Organizational Behavior, Orlando: Dryden Press. 
Olson, B. J. (2004). An Examination of the Dimensions and Outcomes of CEO Power: The Moderating Role of Governance Conditions, PhD Thesis, Oklahoma State University, Oklahoma.

Özaslan, G. ve Gürsel, M. (2008). “Eğitim Yöneticilerinin Güç Tipi Tercihlerinin Değerlendirilmesi”, Selçuk Üniversitesi Ahmet Keleşoğlu Eğitim Fakültesi Dergisi, 25, 351-370.

Özdemir, H. (2008). “Uluslararası İlişkilerde Güç: Çok Boyutlu Bir Değerlendirme”, Ankara Üniversitesi SBF Dergisi, 63(3), 113-144.

Özler, H., Özler, D. E. ve Gümüştekin, G. E. (2007). “Aile İşletmelerinde Nepotizmin Gelişim Evreleri ve Kurumsallaşma, Selçuk Üniversitesi Sosyal Bilimler Enstitüsü Dergisi, 17, 437-450.

Özler, N. D. E. ve Büyükarslan, B. A. (2011). "The Overall Outlook of Favoritism in Organizations: A Literature Review", International Journal of Business and Management Studies, 3(1), 275-285.

Parlatır, İ. (2011). Osmanlı Türkçesi Sözlüğü, Ankara: Yargı Yayınevi.

Parsons, T. (1957). “The Distribution of Power in American Society”, World Politics, 10(1), 123-143.

Paynton, T. (2008). "The Informal Power of Nurses for Promoting Patient Care", OJIN: The Online Journal of Issues in Nursing; http://ojin.nursingworld.org/MainMenuCategories/ANAMarketplace/ANAPeriodicals/OJIN/TableofCo ntents/Vol142009/No1Jan09/ArticlePreviousTopic/InformalPowerofNurses.html.

Peiró, J. M. and Meliá, J. L. (2003). "Formal and Informal Interpersonal Power in Organisations: Testing a Bifactorial Model of Power in Role-sets", Applied Psychology: An International Review, 52(1), 14-35.

Pfeffer, J. and Salancik, G. R. (2003). The External Control of Organisations: A Resource Dependence Perspective, California: Stanford University Press.

Polat, M. ve Meydan, C. H. (2011). “Örgüt Kültürü Bağlamında Güç Eğilimi ve Örgütsel Bağlılık İlişkisinde Örgütsel Özdeşleşmenin Aracılık Rolü”, Atatürk Üniversitesi İktisadi ve İdari Bilimler Dergisi, 25(1), 153-170.

Rahim, M. A. and Buntzman, G. F. (1989). "Supervisory Power Bases, Styles of Handling Conflict with Subordinates, and Subordinate Compliance and Satisfaction", The Journal of Psychology: Interdisciplinary and Applied, 123(2), 195-210.

Rahim, M. A. and Magner, N. R. (1996). "Confirmatory Factor Analysis of the Bases of Leader Power: FirstOrder Factor Model and Its Invariance Across Groups”, Multivariate Behavioral Research, 31(4), 495516.

Rahim, M. A. and Psenicka, C. (1996). "Bases of Leader Power, Workgroup Commitment, And Conflict: A Structural Equations Model”, M. A. Rahim, R. T. Golembiewski and C.C. Lundberg (Eds.), Current Topics in Management, In (31-47). Greenwich, CT: JAI Press.

Rahim, M. A., Antonioni, D. and Psenicka, C. (2001). “A Structural Equations Model of Leader Power, Subordınates' Styles of Handling Conflict and Job Performance", The International Journal of Conflict Management, 12(3), 191-211.

Rahim, M. A. (1988). “The Development of a Leader Power Inventory”, Multivariate Behavioral Research, 23(4), 491-503.

Rahim, M. A. (1989). "Relationships of Leader Power to Compliance and Satisfaction with Supervision: Evidence From a National Sample of Managers", Journal of Management, 15(4), 545-556.

Rahim, M. A. (2004). "Leader Power, Followers' Conflict Management Strategies and Propensity to Leave a Job: A Cross-Cultural Study", Paper presented at the Annual Conference of the International Association for Conflict Management (IACM).

Raven, B. H. (1965). "Social Influence and Power", I. D. Steiner and M. Fishbein (Ed.), Current Studies in Social Psychology, In (371-382), New York: Holt, Rinehart and Winston Inc.

Raven, B. H. (1993). "The Bases of Power: Origins and Recent Development”, Journal of Social Issues, 49(4), 227-251. 
Raven, B. H., Schwarzwald, J. and Koslowsky, M. (1998). “Conceptualizing and Measuring A Power/Interaction Model of Interpersonal Influence”, Journal of Applied Social Psychology, 28(4), 307-332.

Rayner, C., Hoel, H. and Cooper, C. L. (2002). Workplace Bullying: What We Know, Who is to Blame and What Can We Do?, London: Taylor \& Francis Inc.

Riggio, R. E. (2016). Endüstri ve Örgüt Psikolojisine Giriş, B. Özkara (Çev.), Ankara: Nobel Yayıncılık.

Robbins, S. P. and Judge, T. A. (2011). Organizational Behavior, New Jersey: Pearson Education Limited.

Russell, S. (1998). Dimension of Power in The Workplace: An Ethnographic Study, PhD Thesis, Fielding Graduate University, Santa Barbara.

Sakallı, N. (2010). Sosyal Etkiler-Kim Kimi Nasıl Etkiler?, Ankara: İmge Kitabevi.

Salancik, G. R. and Pfeffer, J. (1977). "Who Gets Power-And How They Hold on to It: A Strategic-Contingency Model of Power", Organizational Dynamics, 5(3), 3-21.

Sennett, R. (2011). Otorite, K. Durand (Çev.), İstanbul: Ayrıntı Yayınları.

Seyyar, A. (2007). İnsan ve Toplum Bilimleri Terimleri Ansiklopedik Sosyal Bilimler Sözlüğü, İstanbul: Değişim Yayınlar1.

Şimşek, Ş. ve Çelik, A. (2011). Yönetim ve Organizasyon, Konya: Eğitim Kitabevi.

Thibaut, J. W. and Kelley, H. H. (1959). The Social Psychology of Groups, New York: John Willey.

Thompson, D. R. (2014). Power and Influence of Academic Administrative Staff Members, PhD Thesis, University of Minnesota, Minnesota.

Tönnies, F. (2001). Community and Civil Society, J. Harris and M. Hollis (Çev.), New York: Cambridge University Press.

Tutar, H. (2014). Örgütsel Psikoloji, Ankara: Detay Yayıncılık.

Üsdiken, B. (2005). “Örgüt Kuramında Ana Araştırma Programları”, içinde N. Atsan, 1. Yönetim ve Organizasyon Yaz Semineri (YOYSEM), Akdeniz İ.İ.B.F. Dergisi, 5(10), 274-279.

Üsdiken, S. (2007). “Çevresel Baskı ve Talepler Karşısında Örgütler: Kaynak Bağımlılığı Yaklaşımı”, A. S. Sargut ve Ş. Özen (Der.), Örgüt Kuramları, İçinde (77-132), Ankara: İmge Kitabevi.

Walls, J. L. and Berrone, P. (2015). "The Power of One to Make a Difference: How Informal and Formal CEO Power Affect Environmental Sustainability", Journal of Business Ethics, 145, 293-308, DOI $10.1007 / \mathrm{s} 10551-015-2902-\mathrm{z}$

Weber, M. (1946). Essays in Sociology, H. H. Gerth and C. W. Mills (Çev.), New York: Oxfod University Press.

Weber, M. (1947). The Theory of Social and Economic Organization, New York: Oxfod University Press.

Wilson, P. A. (1999). "A Theory of Power and Politics and Their Effects on Organizational Commitment of Senior Executive Service Members", Administration and Society, 31(1), 120-141.

Wong, P. T. P. (2003). “An Opponent-Process Model of Servant Leadership and A Typology of Leadership Styles", http://citeseerx.ist.psu.edu/viewdoc/download?doi=10.1.1.618.9467\&rep=rep1\&type=pdf, (Erişim Tarihi: 26. 03. 2018).

Yaman, E. ve Irmak, Y. (2010). "Yöneticiler ve Öğretmenler Arasındaki Güç Mesafesi”, Mustafa Kemal Üniversitesi Sosyal Bilimler Enstitüsü Dergisi, 7(13), 164-172.

Yıldırım, E. (1998). “Güç Kavramı ve İstihdam İlişkisi”, Amme İdaresi Dergisi, 31(4), 51-64.

Yılmaz, N., Eroymak, S. ve Demir, M. (2017),. “Örgütlerde İnformal Güç”, R. Erdem (Ed.), Yönetimde İnformalite, içinde (45-76), İstanbul: Beta Yayınevi.

Yücel, D. ve Erkut, H. (2003). "Bilişim Teknolojilerinin Çalışma Yaşam Kalitesi Üzerine Etkisi”, İtüdergisi/d Mühendislik, 2(2), 49-59. 
Zinko, R., Ferris, G. R., Blass, F. R. and Laird, M. D. (2007). Toward A Theory of Reputation in Organizations, Research in Personnel and Human Resources Management, 26(1), 163-204.

Zinko, R., Ferris, G. R., Humphrey, S. E., Meyer, C. J. and Aime, F. (2012). "Personal Reputation in Organizations: Two-Study Constructive Replication and Extension of Antecedents and Consequences", Journal of Occupational and Organizational Psychology, 85(1), 156-180. 